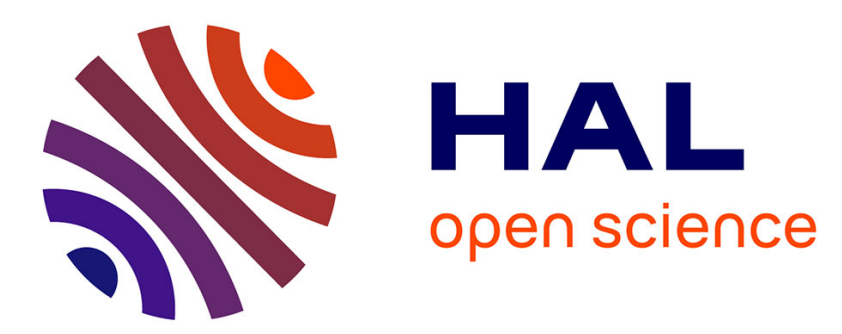

\title{
A review of catalysts for the gasification of biomass char, with some reference to coal
}

\author{
Ange Nzihou, Brian Stanmore, Patrick Sharrock
}

\section{To cite this version:}

Ange Nzihou, Brian Stanmore, Patrick Sharrock. A review of catalysts for the gasification of biomass char, with some reference to coal: Review. Energy, 2013, 58, p. 305-317. 10.1016/j.energy.2013.05.057 . hal-01632394

\section{HAL Id: hal-01632394 \\ https://hal.science/hal-01632394}

Submitted on 23 Jan 2019

HAL is a multi-disciplinary open access archive for the deposit and dissemination of scientific research documents, whether they are published or not. The documents may come from teaching and research institutions in France or abroad, or from public or private research centers.
L'archive ouverte pluridisciplinaire HAL, est destinée au dépôt et à la diffusion de documents scientifiques de niveau recherche, publiés ou non, émanant des établissements d'enseignement et de recherche français ou étrangers, des laboratoires publics ou privés. 


\title{
A review of catalysts for the gasification of biomass char, with some reference to coal
}

\author{
Ange Nzihou $^{\mathrm{a}, *}$, Brian Stanmore $^{\mathrm{b}}$, Patrick Sharrock ${ }^{\mathrm{a}, \mathrm{c}}$ \\ ${ }^{a}$ Université de Toulouse, Mines Albi, CNRS, Centre RAPSODEE, Campus Jarlard, Route de Teillet, F-81013 Albi Cedex 09, France \\ ${ }^{\mathrm{b}}$ The University of Queensland, Brisbane, QLD 4072, Australia \\ ${ }^{\mathrm{c}}$ Université de Toulouse, SIMAD, IUT de Castres, av. Pompidou, Castres 81104, France
}

\begin{abstract}
A B S T R A C T
The best catalysts for promoting char gasification are Group I metals, particularly lithium and potassium, although other metals are active to a lesser extent. The most prevalent metal naturally in biomass char is potassium, which is not only inherently active, but volatilises to become finely distributed throughout the char mass. The formation of an active carbon/potassium complex is frequently proposed. Calcium is the other most common active metal found in biomass, but is far less effective and less volatile. In a gasification system the metals remain as carbonate due to the action of carbon dioxide. The alkali metals can react with silica to form silicates, which prevents catalytic action. Transition metals can also participate in catalysis of gasification; iron accelerates gasification and nickel prevents carbon deposition, which helps in conditioning biomass-derived syngas. Volatile iron pentacarbonyl has been identified as a promoter of the char gasification step, with catalytic activity related to the finely dispersed low-valency metal atoms generated during the thermo-decomposition of biomass.
\end{abstract}

\section{Introduction}

The availability of liquid fuels from conventional petroleum sources is occupying the attention of energy companies as extraction rates approach a peak [1]. However, the recent discovery of large supplies of natural gas in coal and shale seams in the US and elsewhere offers the possibility of a reprieve. Transport fuels can be manufactured from natural gas by steam reforming and then the methanol/dimethyl ether, or methanol/ZSM5 [2] routes. Alternatively the Fischer-Tropsch conversion can be employed [3]. In the longer term however, the introduction of renewable technologies based on biomass will probably be necessary.

The transition from a petroleum-based economy to one based on biomass requires new strategies since the developed petrochemical technologies are not valid to process biomass-derived compounds. The cost of biomass processing must be decreased by designing new technologies and catalytic systems, because those employed for hydrocarbons are not adapted to the molecular structure of biomolecules. The number of reports on the catalytic transformation of biomass has risen from 16,000 to over 22,000 papers during the past five years, showing sustained interest in

* Corresponding author. Tel.: +33 563493222; fax: +33 563493099 .

E-mail address: ange.nzihou@mines-albi.fr (A. Nzihou). biomass transformations using various catalytic systems. In the future, biomass will continue to emerge as the most abundant and bio-renewable resource for sustainable production of chemicals and fuels.

Biomass is regarded as a truly renewable source, and when gasified can convert cellulose and lignin, which cannot be utilised in current fermentation processes [4]. Like all chemical reactions, the rate of the gasification process is affected by the process conditions, and is catalysed/inhibited by a number of different species. This paper examines these effects with the purpose of identifying those that best promote the reaction of the residual char which remains after pyrolytic destruction of the carbohydrate matrix.

A schematic of the catalysed gasification of biomass with steam is presented in Fig. 1 [5]. Complex interactions are indicated, with any catalyst likely to interact with the char, the tar and the gas phase. Tar treatment will not be discussed in this review although non-condensible tars may contribute up to $20 \%$ of the volatile material formed during initial pyrolysis. Their presence confounds the issue of char gasification because any catalytically active materials in the system will affect the performance of a gasifier with respect to both tar reforming and char gasification. In addition, the tar itself will inhibit the gasification reaction [6].

Biomass gasification is generally carried out in the temperature range $800-900{ }^{\circ} \mathrm{C}$, with steam-to-carbon ratios of $0.8-1.5: 1$ [7]. The favourite contacting device for large scale operation is the 


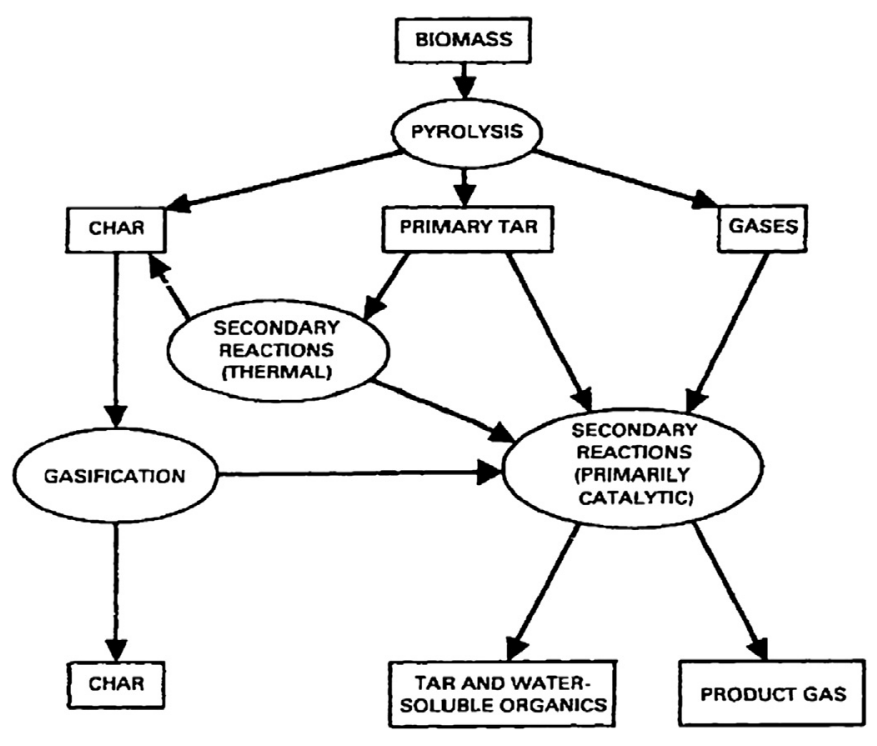

Fig. 1. Reaction scheme for biomass gasification [5].

fluidised bed, while smaller units are generally moving beds operated in co- or counter-current regimes. Operating pressures are generally atmospheric, as elevated pressures introduce complications in feeding fibrous biomass. Steam is generally employed as the gasifying agent to give a hydrogen-rich product, with air and sometimes oxygen as an oxidant. The carbon dioxide formed during gasification also acts as a gasifying reagent.

Because the reactions of the carbonaceous char with steam and carbon dioxide are comparatively slow, it has been found that during gasification much of the initial mass loss from biomass consists of volatiles released by pyrolysis e.g. Refs. [8,9]. Volatile matter, which includes water, permanent gases such as $\mathrm{CO}$ and $\mathrm{CO}_{2}$, hydrocarbons and tars may comprise over $80 \%$ of the mass loss, see for example the review by Di Blasi (2008) [10]. As a result, many of the overall conversion reactions take place in the gas phase.

Some modern approaches take advantage of this situation by separating the pyrolysis and char gasification processes, so that each may be independently optimised [11,12]. Recent developments to produce higher energy gas involve a process in which the combustion and gasification steps are carried out in separate circulating fluidised beds. This technique has been employed successfully at the pilot, demonstration and small commercial scale $[13,14]$

As indicated in Fig. 1, the tars formed during the initial pyrolysis of biomass can influence the subsequent char gasification step by undergoing cracking on the char surface to deposit carbon, and by inhibiting the access of gasifying reagents. The usual bed materials which have been developed to inhibit tar formation, such as olivine and Ni-doped materials, see for e.g. Refs. [15-21] will therefore play a role in subsequent char gasification.

Reviews of the control of tars during gasification have been published by Han and Kim in 2008 [22] and by Shen and Yoshikawa in 2013 [23]. The conditioning of syngas has been reviewed by Yung et al. [24]. The mean tar content in the raw syngas from different gasifiers is reported to be 50 and $0.5 \mathrm{~g} \mathrm{~N} \mathrm{~m}^{-3}$ from fixed bed gasifiers in countercurrent and cocurrent configurations respectively [22]. For fluidised beds, the contents are 12 and $8 \mathrm{~g} \mathrm{~N} \mathrm{~m}^{-3}$ respectively for bubbling and circulating beds. In each case a wide range of values has been reported. It is claimed by Han and Kim that most downstream processes such as energy generation and chemical conversion require the tar concentration to be less than $0.05 \mathrm{~g} \mathrm{~m}^{-3}$.
The slower gasification step subsequent to pyrolysis, namely the reaction of the residual char with steam and/or carbon dioxide, is accelerated by catalysts such as alkaline and alkaline earth metals, which may be inherently present, or added for the purpose. The characteristics of biomass feedstock can be affected by harvesting time or growth location, and by processes such as transportation, storage and debarking. During these steps, the biomass can remain in contact with water, which may cause leaching or extraction of the minerals present, mainly the alkaline metals.

\section{Catalytic and inhibition mechanisms during char gasification by $\mathrm{CO}_{2}$ and $\mathrm{H}_{2} \mathrm{O}$}

In order to evaluate catalysts, it is necessary to identify those inherent factors apart from metal catalysts which can affect gasification rates. It is clear that both the structure of the char and the nature of its surface [25], and the gaseous environment [26] have a strong influence on the rate of attack. In particular, both carbon monoxide and hydrogen can inhibit the gasification process, and pyrolysis tars also interfere with the reaction [27].

The formation of char is discussed by Di Blasi [28] in a comprehensive review of the combustion and gasification behaviour of biomass char. She points out that under equivalent conditions the rate of gasification of biomass char with steam is $4-10$ times faster than lignite char, itself a reactive char in comparison to higher rank coals.

The yield of char from various biomass types, final temperature and heating rates is compared in Fig. 2 (Fig. 1 from Di Blasi), where it can be seen that hardwoods, higher temperatures and rapid pyrolysis result in less char being formed. In the latter case this is probably due to less contact time for secondary cracking of tars to occur on the char surface, see Fig. 1. The char yield is mostly $5-40 \%$ of the initial biomass on a dry basis. The higher char yields produced from agricultural residues are partly the result of the higher lignin contents of these materials.

\subsection{Char structure and pyrolysis conditions}

The nature of the residual char depends on the initial heating conditions experienced by the biomass. The temperatures required for destructive pyrolysis are typically around $300{ }^{\circ} \mathrm{C}$ for hemicellulose, $300-400^{\circ} \mathrm{C}$ for cellulose and $350-450{ }^{\circ} \mathrm{C}$ for lignin [28]. The composition of products has been examined with a view to

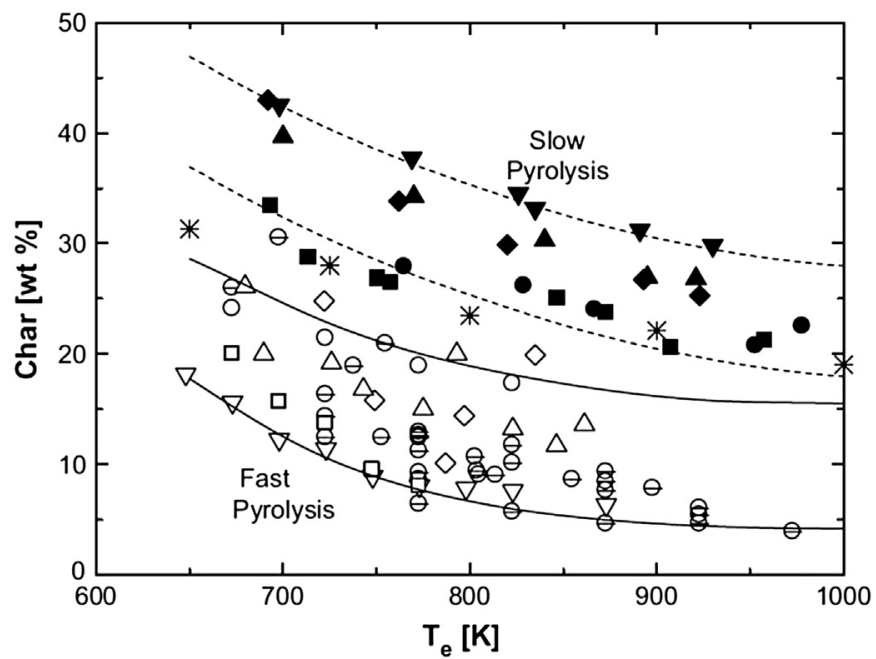

Fig. 2. Char yield from different biomass types under various pyrolysis conditions [28]. 
predicting their distribution from these three basic components [29], but interactions and the action of inorganics preclude application of the additivity law. It is reported that the breakdown of 'pure' lignin results predominantly in char, whereas the product is predominantly tar with 'pure' cellulose [30].

From a pyrolysis study of 10 different plant species, it appears that the chemical and physical properties of the chars are remarkably similar, despite their origin from a wide range of plants and morphologies [31]. It was noted by DeGroot and Richards [32] that the $\mathrm{CP}$ (cross polarization)/MAS (magic angle spinning) ${ }^{13} \mathrm{C}$ NMR spectra of chars prepared from untreated and catalyst-treated wood indicate that their chemical structures were very similar. Therefore any catalytic effects are not associated with the catalyst's influence on the formation of the pyrolytic char. Similarly, after pyrolysis of hybrid poplar without the addition of either $\mathrm{K}_{2} \mathrm{CO}_{3}$ or $\mathrm{Na}_{2} \mathrm{CO}_{3}$, the cellular structure of the wood was preserved [33]. Additionally, this cellular structure remained intact during most of the gasification process. However, the addition of $\mathrm{K}_{2} \mathrm{CO}_{3}$ and $\mathrm{Na}_{2} \mathrm{CO}_{3}$ before pyrolysis caused a degradation of the regular cellular structure, and an increase in the rate of gasification of the resulting char.

Biomass chars are highly disordered carbonaceous materials that have a short-range polycrystalline structure. They consist of small aromatic structural units, with the oxygen present mostly within heterocyclic and phenolic groups [34]. The structural units are cross-linked by ether and olefinic linkages. The effect of pyrolysis temperature on char structure is illustrated in Fig. 3, where a more ordered, graphitic structure results from condensations as temperature increases [35]. As a result, in low temperature gasification processes there are many carbon atoms in exposed edge positions and liable to attack by gas molecules. The effect of structural order in the carbon matrix on catalysed gasification rates is demonstrated by Table 1 , where the addition of a potassium catalyst has a greater effect with regular graphitic-type structures.

In a study of gasification kinetics, Asadullah et al. [25] prepared chars from Australian Mallee wood by rapid pyrolysis in a fluidised bed, and characterised them by a variety of techniques, including Raman spectroscopy. The spectra indicated that the formation of an amorphous carbon structure with smaller polyaromatic rings predominates in chars from bigger particles and at lower temperatures. Condensed and larger aromatic ring systems are preferentially formed in chars from smaller particles and at higher temperature.

When Mallee char was subjected to steam gasification, it was observed that there was preferential destruction of smaller rings, leading to a residual content of larger structures [36]. A similar experience occurred with the catalytic gasification reactions of brown coal with oxygen, where reactions were localised on the sites associated with the catalysts [37,38]. The preferential removal of smaller aromatic ring systems and the persistence of crosslinking structures in the presence of a catalyst mean that the large aromatic ring systems are increasingly concentrated with little flexibility, affecting the dispersion of catalyst. This 'selective gasification' applied to the wood of the tree because of low values of AAEM (alkali and alkaline earth metals), but did not occur with leaves and bark which were catalytically reacted.

Significant modifications to char structure produced by steam gasification of cane trash are described by Keowna et al. [39], even when the char conversion was minimal, resulting in a drastic reduction in the intrinsic reactivity of char with air at $400{ }^{\circ} \mathrm{C}$. The decreases were not related to the loss of inherent catalytic material, but to major changes in char structure, including the transformation of smaller ring systems (3-5 fused rings) into large ring systems ( $>6$ fused rings). It is believed that the intermediates of char-steam reactions, especially hydrogen, penetrated deep into the char matrix to induce the ring condensation reactions.

It was found [40] that an increasing concentration of alkali metals in two grasses lowers the maximum temperature of the cellulose peak in the pyrolysis profile, and results in the formation of more char (i.e. less volatiles). The wide variation measured in the activation energies during the pyrolysis of four biomass types was attributed to the action of alkali metals, which leads to a decrease in value [41] in commercial gasifiers.

The behaviour of coals under conditions likely to be encountered in high pressure, entrained flow gasifiers $\left(1000-1400{ }^{\circ} \mathrm{C}\right.$, $2 \mathrm{MPa}$ ) under $\mathrm{CO}_{2}$ were examined by Hodge et al. [42]. The particle

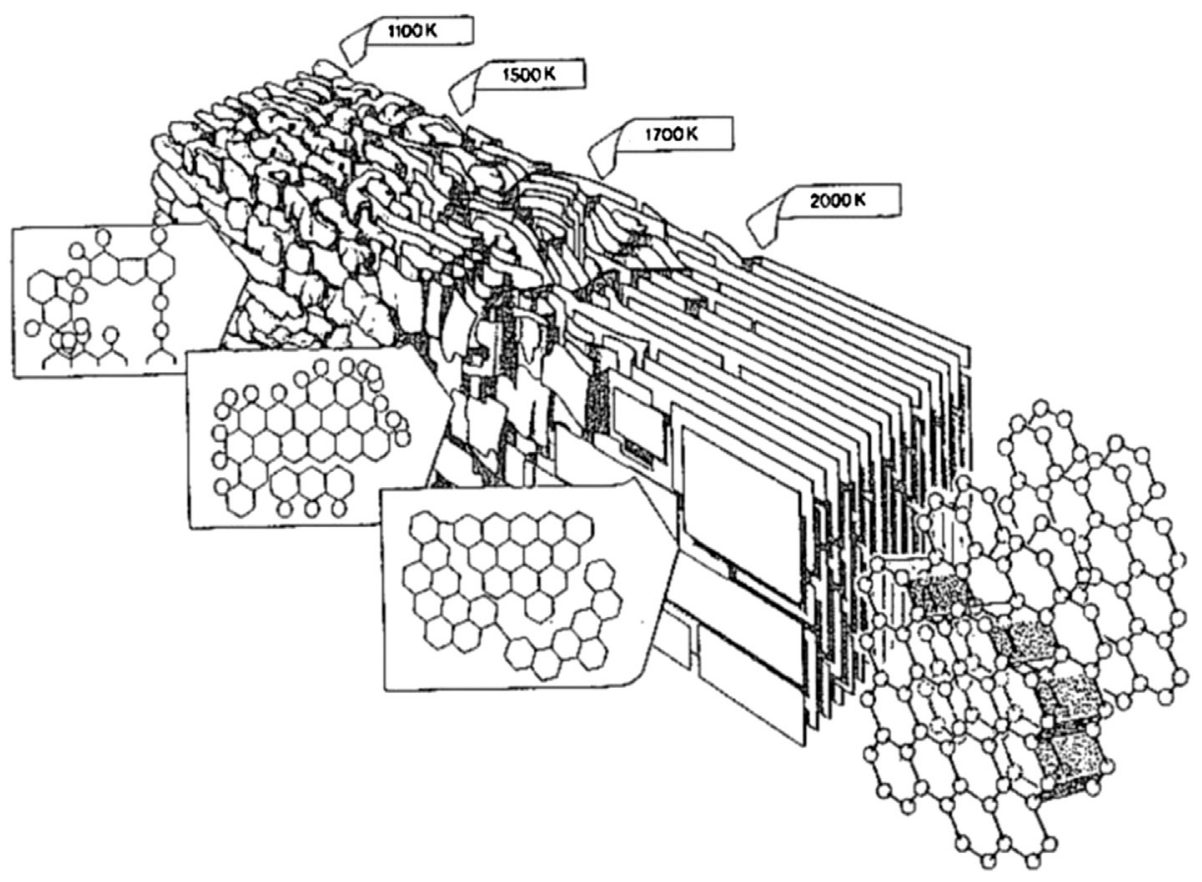

Fig. 3. Representation of the structure of chars prepared at different temperatures, showing the progression towards graphitic structures at high temperature [35]. 
Table 1

Effect of potassium carbonate on char gasification rates of various carbonaceous materials by steam [5].

\begin{tabular}{|c|c|c|c|}
\hline Char source & $\begin{array}{l}\text { Operating } \\
\text { temperature } \\
\left({ }^{\circ} \mathrm{C}\right)\end{array}$ & $\begin{array}{l}\text { Content } \\
\mathrm{K}_{2} \mathrm{CO}_{3} \\
\text { (wt\%) }\end{array}$ & $\begin{array}{l}\text { Ratio of rates } \\
\text { catalysed/ } \\
\text { uncatalysed }\end{array}$ \\
\hline Wood & 750 & 17 & 4.9 \\
\hline Lignite & 700 & 10 & 3.8 \\
\hline Sub-bituminous coal & 700 & 10 & 7.5 \\
\hline Bituminous coal, hvB* & 700 & 10 & 16 \\
\hline Anthracite & 800 & 10 & 25 \\
\hline Graphite & 900 & 10 & 470 \\
\hline
\end{tabular}

*hvB = high volatile B bituminous coal, ASTM classification.

structure indicates fusion and exfoliation, with thin-walled char cenospheres predominant. Application of an appropriate effectiveness model suggests that the kinetics follow an extension of those at low temperature. There is evidence that biomass chars may exhibit some fusion in a similar fashion under extreme conditions.

It was reported after a TGA (thermal gravimetric analysis) study of the $\mathrm{CO}_{2}$ gasification kinetics of biomass char at elevated pressures that the total pressure has little effect on reactivity, indicating that both external and internal gas diffusion processes do not influence the reaction for temperatures and pressures up to $900{ }^{\circ} \mathrm{C}$ and $2 \mathrm{MPa}$ [43]. A similar result is reported for coal chars [42]. This implies that the apparent rate of reaction should be equal to the chemical rate of reaction. Global char gasification reactivity decreases by increasing the pyrolysis pressure [43], mainly due to the pressure effect on intrinsic reactivity of chars passing through a liquid phase during pyrolysis.

Some biomass chars such as those prepared by flash pyrolysis may contain large amounts of residual oxygen. For example, the material tested by Chaudhari et al. [9] contained 32.4\% oxygen, and lost up to $40 \%$ of its mass by simple thermal treatment at $800{ }^{\circ} \mathrm{C}$ under an inert atmosphere. The dominant product was methane.

In accordance with the typical oxidation behaviour of coal char, biomass chars prepared at low temperatures were found to be more reactive to oxygen than the ones prepared at high temperature, and char morphology had a greater influence on reactivity than the catalytic activity of any residual metals [25].

\subsection{Catalytic mechanisms}

In 1984 the literature on the potassium catalysed gasification of carbon in $\mathrm{CO}_{2}$ was critically reviewed by Moulijn et al. [44] with respect to the mechanism. It was concluded that bulk intercalation compounds $\left(\mathrm{C}_{8} \mathrm{~K}, \mathrm{C}_{24} \mathrm{~K}\right.$, etc.) are not present under gasification conditions; also other metallic K-species are not the major species during gasification. It is shown that the catalytic activity can be attributed to an oxygen transfer cycle with either reduction of carbon or decomposition of the oxygenated complexes as the ratedetermining step. In this catalytic cycle only oxidic potassium species are involved.

Catalysis leads to increasing specific reaction rates with increasing burnout, as the catalyst becomes more and more concentrated and hence available to the carbon remaining. If there is significant catalytic activity, the reaction rate should increase with extent of conversion (i.e. carbon gasification), because the ratio of catalyst to carbon increases e.g. Moilanen et al. [45]. Edge carbons are more accessible, although a catalyst particle can generate pits and channels which open up more reactive area when oxygen is available [46]. Reactive or active area dictates the progress of carbon removal. The dispersion of the metal is important, as small domains can agglomerate at higher temperatures; thus becoming less effective.
Kajita et al. [47] found that simple first-order kinetics was implausible for catalytic gasification regardless of the mode of contact between the catalyst and char carbon matrix. If a catalyst is highly dispersed in/on the carbon matrix, the rate of catalytic gasification will be a function of not the amount of residual carbon but the effective amount of the catalyst, and will obey zeroethorder kinetics rather than first-order kinetics with respect to the residual carbon amount.

Both the $\mathrm{C}-\mathrm{CO}_{2}$ and $\mathrm{C}-\mathrm{H}_{2} \mathrm{O}$ reactions proceed with similar overall mechanisms, involving dissociation of the reactant at the surface of the carbon, formation of an activated surface complex (or complexes) on the surface, and then desorption of product species from the surface. With steam the products are a syngas consisting of a nearly equimolar mixture of hydrogen and carbon monoxide according to: $\mathrm{C}+\mathrm{H}_{2} \mathrm{O} \rightarrow \mathrm{CO}+\mathrm{H}_{2}$, while carbon dioxide gives predominantly carbon monoxide when $\mathrm{C}+\mathrm{CO}_{2} \rightarrow 2 \mathrm{CO}$.

A review by Di Blasi [28] details proposed mechanisms for the gasification reactions for $\mathrm{O}_{2}, \mathrm{CO}_{2}$ and $\mathrm{H}_{2} \mathrm{O}$. The $\mathrm{CO}_{2}$ reaction is regarded as simpler than that with steam, with the following steps.

$$
\mathrm{C}_{\mathrm{f}}+\mathrm{CO}_{2} \rightarrow \mathrm{C}(\mathrm{O})+\mathrm{CO} \quad \text { rate } k_{1}
$$

followed by: $\mathrm{C}(\mathrm{O})+\mathrm{CO} \rightarrow \mathrm{C}_{\mathrm{f}}+\mathrm{CO}_{2} \quad$ rate $k_{2}$

$$
\text { and: } \quad \mathrm{C}(\mathrm{O}) \rightarrow \mathrm{CO} \quad \text { rate } k_{3}
$$

where $C_{f}$ is an active site and $C(O)$ a carbon-oxygen complex. Assuming the steady state assumption for the $\mathrm{C}(\mathrm{O})$ complex, the overall rate can be expressed in Langmuir-Hinshelwood form as:

$$
r_{\mathrm{c}}=\frac{k_{1} P_{\mathrm{CO}_{2}}}{1+\left(k_{2} / k_{3}\right) P_{\mathrm{CO}}+\left(k_{1 / k_{3}}\right) P_{\mathrm{CO}_{2}}}
$$

The steam reaction is simplified to

$\mathrm{C}_{\mathrm{f}}+\mathrm{H}_{2} \mathrm{O} \rightarrow \mathrm{C}(\mathrm{O})+\mathrm{H}_{2}$

with the oxygen intermediate either disengaging from the surface: $\mathrm{C}(\mathrm{O}) \rightarrow \mathrm{CO}$, or being reduced by hydrogen: $\mathrm{C}(\mathrm{O})+\mathrm{H}_{2} \rightarrow \mathrm{C}_{\mathrm{f}}+\mathrm{H}_{2} \mathrm{O}$. A similar $\mathrm{L}-\mathrm{H}$ equation can be deduced. However a parallel hydrogen inhibition reaction is also taking place, with hydrogen reacting directly with the carbon. The paper tabulates a summary of the experimentally-determined kinetic parameters for both reactions, and refers the reader to a number of articles concerning catalytic effects.

In a significant experimental study, McKee [48] proposes a mechanism for the catalytic effect of alkali carbonates in an atmosphere rich in carbon dioxide, which involves decomposition to the metal:

$\mathrm{M}_{2} \mathrm{CO}_{3}+2 \mathrm{C} \rightarrow 2 \mathrm{M}+3 \mathrm{CO}$

followed by recarbonation $2 \mathrm{M}+\mathrm{CO}_{2} \rightarrow \mathrm{M}_{2} \mathrm{O}+\mathrm{CO}$

or $\mathrm{M}_{2} \mathrm{O}+\mathrm{CO}_{2} \rightarrow \mathrm{M}_{2} \mathrm{CO}_{3}$

$2 \mathrm{C}+\mathrm{CO}_{2} \rightarrow 2 \mathrm{CO}$

The evidence for this came from thermodynamic considerations, coupled with observations that the metal oxides were not stable at temperatures above $100-200{ }^{\circ} \mathrm{C}$ under carbon dioxide, but were rapidly converted to carbonates. The catalytic gasification then occurs near the melting point of the carbonate phase, as indicted on the thermal gravimetric analysis (TGA) traces of Fig. 4 


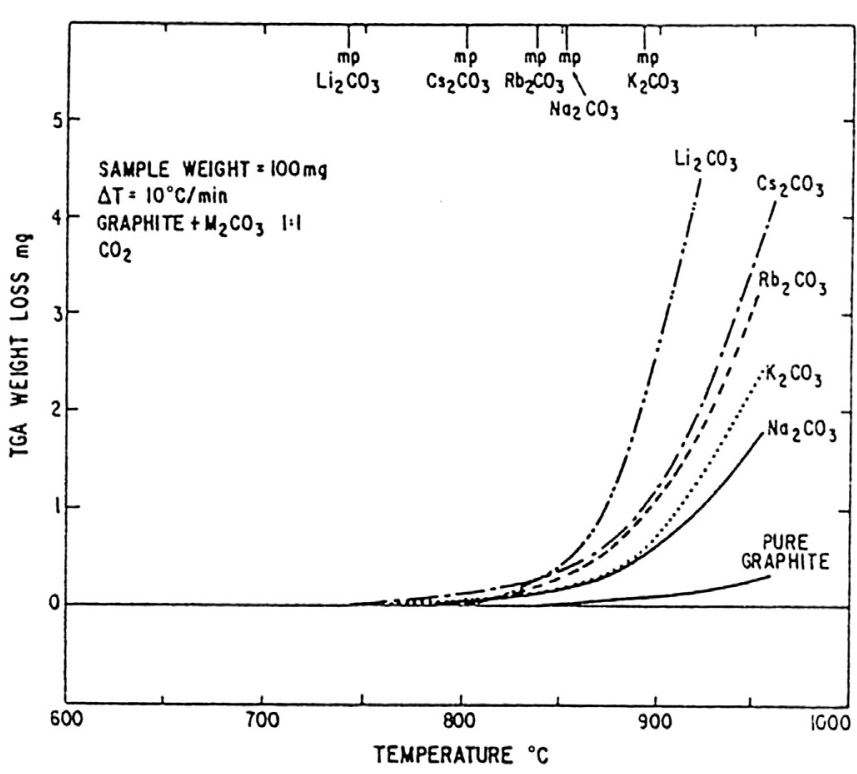

Fig. 4. Action of various alkali carbonates on the graphite $-\mathrm{CO}_{2}$ reaction [46].

[46]. In addition, some sublimation of the alkali metal took place during the reactions, and a thermodynamic consideration of the system indicates that the initial decomposition reaction is likely. At $1100 \mathrm{~K}\left(827^{\circ} \mathrm{C}\right), \mathrm{K}, \mathrm{Cs}$ and $\mathrm{Rb}$ are all in the gaseous state, while $\mathrm{Na}$ and $\mathrm{Li}$ exert very high vapour pressures. The first reaction is thought to be rate-limiting.

For steam gasification the sequence is considered once again to be via the metal

$$
\begin{aligned}
& \mathrm{M}_{2} \mathrm{CO}_{3}+2 \mathrm{C} \rightarrow 2 \mathrm{M}+3 \mathrm{CO} \\
& 2 \mathrm{M}+2 \mathrm{H}_{2} \mathrm{O} \rightarrow 2 \mathrm{MOH}+\mathrm{H}_{2} \\
& 2 \mathrm{MOH}+\mathrm{CO} \rightarrow \mathrm{M}_{2} \mathrm{CO}_{3}+\mathrm{H}_{2} \\
& 2 \mathrm{C}+2 \mathrm{H}_{2} \mathrm{O} \rightarrow 2 \mathrm{CO}+2 \mathrm{H}_{2}
\end{aligned}
$$

In a separate experiment [46], the action of the carbonate on the planar surfaces of graphite was observed under a hot-stage microscope. In contrast to the behaviour of the carbonates under oxygen, no mobility or channelling of the small catalyst particles was observed. Vaporisation of the metal has been observed in practice, and accounts for both the good dispersion and hence effectiveness of the catalysts, but also contributes to their loss.

It was concluded by Huang et al. [49] that for a coal char tested at atmospheric pressure, the $\mathrm{C}-\mathrm{H}_{2} \mathrm{O}$ and $\mathrm{C}-\mathrm{CO}_{2}$ reactions take place at different sites on the carbon surface. This is in contrast to the results of Roberts and Harris (2007) [50], who found that at higher pressures the two gases compete for active sites. Huang et al. found that the two rates were additive, and could be described adequately by the appropriate Langmuir-Hinshelwood relations, as did Kajita et al. [47].

Delannay et al. [51] determined that the reaction of a $\mathrm{KOH}$ loaded graphite powder with atmospheric pressure of steam in the temperature range $700-900 \mathrm{~K}$ proceeds via two successive stages. During stage I hydrogen and hydrocarbons are evolved at a high rate, but no $\mathrm{CO}$ or $\mathrm{CO}_{2}$. This stage ceases after the equivalent of 0.5 molecules of $\mathrm{H}_{2}$ per potassium in the sample are produced. During stage II gasification proceeds catalytically at a much reduced rate with the production of one $\mathrm{CO}$ molecule per equivalent $\mathrm{H}_{2}$ molecule. The absence of $\mathrm{CO}$ or $\mathrm{CO}_{2}$ evolution during stage I indicates the formation of a stable oxygen containing compound. This compound may be decomposed thermally by heating the sample up to $1300 \mathrm{~K}$. CO evolves almost exclusively during this high temperature treatment. These results suggest a step reaction mechanism involving

1. the dissociative adsorption of water forming $\mathrm{C}-\mathrm{H}$ and $\mathrm{C}-\mathrm{OH}$ (phenol) groups,

2. the formation of a $\mathrm{K}-\mathrm{O}-\mathrm{C}$ entity (phenolate), from the reaction of $\mathrm{KOH}$ with the phenol groups,

3. the decomposition of these $\mathrm{K}-\mathrm{O}-\mathrm{C}$ entities to give $\mathrm{CO}, \mathrm{K}_{2} \mathrm{O}$ and perhaps metallic potassium and

4. the formation of $\mathrm{KOH}$ from reaction of $\mathrm{K}_{2} \mathrm{O}$ with water.

The transition from stage I to stage II is due to the consumption of $\mathrm{KOH}$ to form $\mathrm{K}-\mathrm{O}-\mathrm{C}$ species. The rate of the catalytic reaction (stage II) is controlled by the slowest step (3).

The X-ray photoelectron spectra of $\mathrm{K}$ and $\mathrm{O}$ peaks of carbon impregnated with potassium carbonate were dramatically decreased by evacuation at $650{ }^{\circ} \mathrm{C}$ [52]. When oxygen was introduced onto this surface, remarkable growth of these peaks was observed at room temperature; however, in the case of contact with carbon dioxide, a temperature as high as $650{ }^{\circ} \mathrm{C}$ was required to cause the same effect. These results support a redox cycle catalytic mechanism for the reduction of carbon dioxide with carbon.

The activity pattern of potassium carbonate-containing coal char during gasification with low pressures of steam was shown to consist of at least three stages of activity [53]. The relative importance of these stages, that occur at different burn-off levels, is influenced by the pretreatment temperature, the catalyst loading and the sequence of catalyst addition and coal pyrolysis. It was postulated that three processes occur simultaneously during pretreatment: oxygen retention by potassium, intercalation of potassium and potassium carbonate crystallisation. It follows that the maximum activity of alkali metals correlates with the oxygen content of carbon and that intercalation depends on the degree of graphitisation of carbon.

The conclusion drawn by Hüttinger et al. [54,55] from a study of steam gasification with the addition of a range of potassium is a catalytic activation process, whereby $\mathrm{KOH}$ is formed from all salts. Potassium hydroxide therefore represents the key component of all the activation processes, from which finally the active species, a non-stoichiometric potassium/oxygen compound $\mathrm{K}_{x} \mathrm{O}_{y}(y<x)$ is formed. It acts as a dissociation centre for water and transfers the oxygen to the carbon surface, from which carbon monoxide is finally desorbed. The following activity sequence was found: $\mathrm{KOH} \sim \mathrm{K}_{2} \mathrm{CO}_{3} \sim \mathrm{KNO}_{3}>\mathrm{K}_{2} \mathrm{SO}_{4}>\mathrm{KCl}$.

Measurements by Kajita et al. [47] suggest that catalytic and non-catalytic reactions proceed in parallel during steam gasification. This conclusion was reached because the demineralised cedarwood and bamboo chars which were tested showed first order kinetics with respect to residual carbon fraction for the whole burnout, and at all $\mathrm{H}_{2} \mathrm{O}$ and $\mathrm{H}_{2}$ concentrations. To quote the authors "the density of active sites on the char surface was maintained during the course of gasification regardless of significant or insignificant progress of pore development".

\subsection{Inhibition mechanisms}

The influence of carbon monoxide on the $\mathrm{CO}_{2}$ gasification reaction was studied by McKee [48], and the results are depicted in Fig. 5, where a significant decline in reactivity is apparent. The effect is more pronounced in undoped graphite, compared to graphite with $5 \%$ potassium present. Gea et al. [56] postulate the 


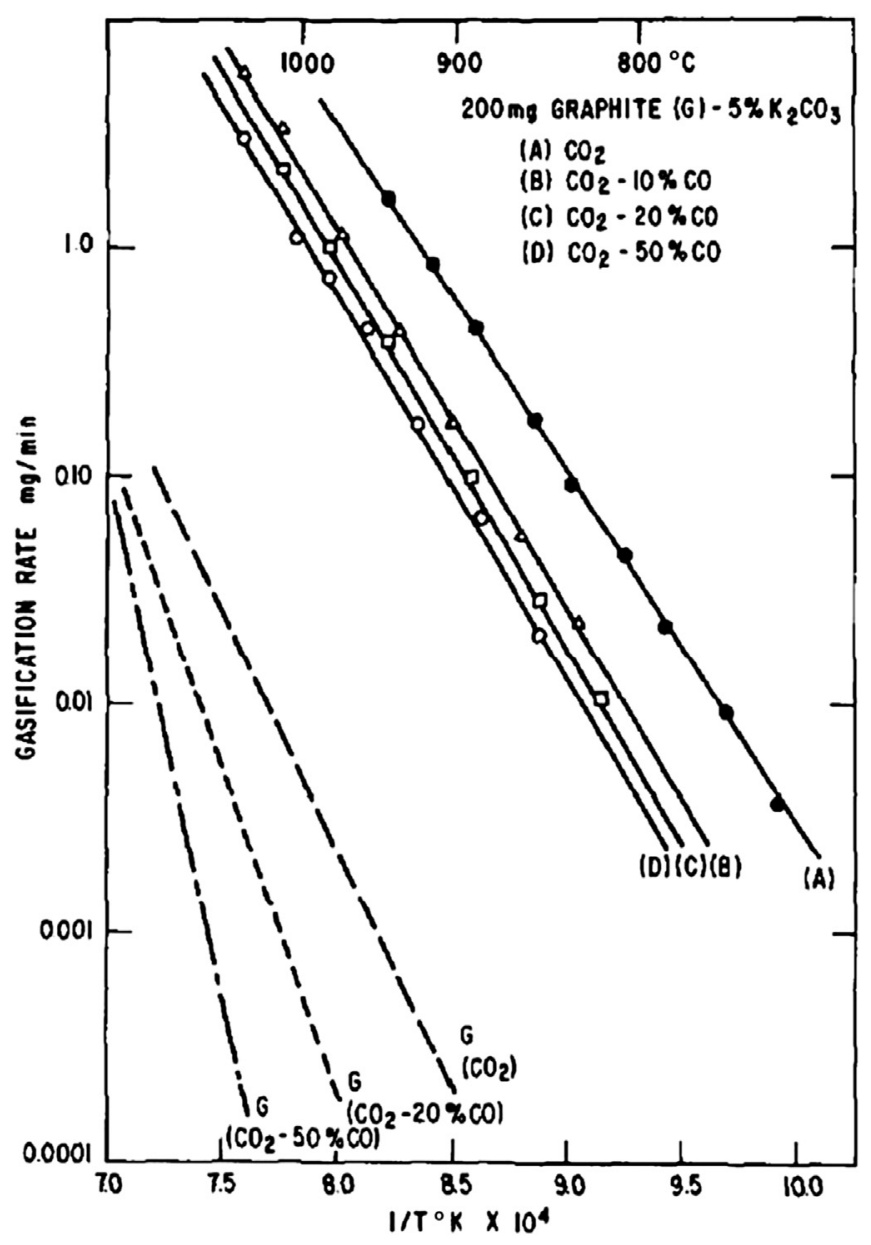

Fig. 5. The effect on reactivity of potassium catalyst, and also carbon monoxide in the gas phase [48].

formation of surface intermediates written as [-COM] and [$\left.\mathrm{CO}_{2} \mathrm{M}\right]$, which then decompose to give $\mathrm{CO}$ and regenerate the carbonate. It is proposed by Mitsuoka et al. [57] that CO inhibits alkaline earth catalysts by disproportionating on the catalyst surface to carbon and $\mathrm{CO}_{2}$, thus shielding it from gases. The sequestering of active sites and carbon deposition could proceed in parallel. The CO formed also inhibits the alkali reduction reactions, which causes the loss of catalytic sites during the previous pyrolysis step. Thus CO could increase the total number of active sites available for the gasification step, which in turn increases the gasification rate.

A number of studies e.g. Refs. $[6,45]$ which have shown that hydrogen strongly inhibits steam gasification reactions, are listed by Fushimi et al. [6]. The latter extended this work by gasifying a char made from Radiata pine with steam in argon, and then with the addition of various concentrations of hydrogen. The presence of $25 \mathrm{kPa}$ of hydrogen at $800{ }^{\circ} \mathrm{C}$ lowered the kinetic constant by almost an order of magnitude. At low conversions the effect is attributed to reverse oxygen exchange, when an adsorbed oxygen intermediate is stripped of oxygen to regenerate the carbon:

$\mathrm{C}(\mathrm{O})+\mathrm{H}_{2} \rightarrow \mathrm{C}+\mathrm{H}_{2} \mathrm{O}$

At high conversions the process is believed to be dissociative hydrogen adsorption, where hydrogen is preferentially adsorbed to form a hydrogen complex:

$\mathrm{C}+1 / 2 \mathrm{H}_{2} \rightarrow \mathrm{C}(\mathrm{H})$
Huang assumes that hydrogen enters into the reaction sequence for steam gasification and that carbon monoxide participates only in the $\mathrm{CO}_{2}$ sequence.

The influence of pyrolysis tars on the gasification process was investigated by Fushimi et al. [6] using levoglucosan $\left(\mathrm{C}_{6} \mathrm{H}_{10} \mathrm{O}_{5}\right)$ as a tar proxy. It was found that vapour-phase levoglucosan strongly inhibits the steam gasification of woody biomass char. The carbohydrate itself decomposes to give some non-condensible gases ( $\mathrm{CO}$ and $\mathrm{CO}_{2}$ ) and elemental hydrogen, but the inhibition was greater than could be explained only by the amount of hydrogen generated. It was therefore concluded that other pyrolysates must be active.

The loss in reactivity of biomass char during gasification by mixed steam and carbon dioxide was attributed by Abu El-Rub et al. [20] to the deposition of coke on the carbon surface, resulting from the decomposition of aromatic tars. A similar result is noted by Hosokai et al. [58]. The high concentration of labile oxygenated compounds in the tars would enhance this effect.

The gas composition produced from biomass is significantly different when produced in the presence of an active alkali catalyst compared to the product from the uncatalyzed reaction [59]. In addition to the reaction of carbon with steam the most important reaction in both systems is the water-gas shift reaction: $\mathrm{CO}+\mathrm{H}_{2} \mathrm{O} \rightarrow \mathrm{H}_{2}+\mathrm{CO}_{2}$. The effect of the water-gas shift in catalysed biomass gasification is a marked increase in hydrogen and carbon dioxide at the expense of the carbon monoxide in the product gas.

\subsection{Loss of catalyst}

As alkali compounds have high vapour pressures, catalysts based on them tend to suffer evaporative losses during extended use at gasifier temperatures. One reason why the Exxon coal gasification system was abandoned in the 1980s was the high consumption rate of potassium catalyst. In a study of $\mathrm{K}$ loss from wood during pyrolysis under an inert atmosphere by Kowalski et al. [60], a significant loss of potassium was observed around $300{ }^{\circ} \mathrm{C}$. The release was believed to be a result of the volatilisation of alkalis from organic salts, and at around $600{ }^{\circ} \mathrm{C}$ the alkali signal increased again. The latter was interpreted as the start of the evaporation of inorganic salts, namely $\mathrm{KCl}$. The loss of potassium is not a penalty with inherent ash, but it means that calcium is generally employed in tailored catalysts.

A system in which potassium is recovered has been proposed by Sueyasu et al. [7]. The feed biomass is soaked in K solution, then dried and pyrolysed. The char and gaseous products are then passed through a bed comprised of recycled char which acts as the gasifier, with steam and air/oxygen also supplied. Product gas is removed from the vessel, while the spent char is washed to recover potassium. The $\mathrm{K}$ solution is then recycled to the feed. In this scheme, most of the potassium is retained and high carbon conversions are achieved.

As part of an extensive investigation into the behaviour of Victorian brown coal [37,61], an extremely low rank material which consequently exhibits many of the properties of biomass, it was found that sodium is active during pyrolysis in the formation and simultaneous (catalytic) destruction of soot on the char surface. These effects are closely linked to the volatilisation of $\mathrm{Na}$ from the char, which commenced at temperatures around $300^{\circ} \mathrm{C}$, and rose to about $50 \%$ at $900{ }^{\circ} \mathrm{C}$. Calcium is not devolatilised from brown coal at these temperatures.

Jiang et al. [62] examined AAEM loss from maize stalk, rice husk and cotton stalk during pyrolysis at $900{ }^{\circ} \mathrm{C}$ and subsequent gasification in steam at the same temperature. The results indicate that over half of alkali metals $(\mathrm{K}, \mathrm{Na})$ and one-third of alkaline earths (Ca, Mg) were released during pyrolysis. In the subsequent char 
gasification process a further $12-34 \%$ of alkali metal and $12-16 \%$ of alkaline earth metals were lost. The release of each metal was almost proportional to burnout for both processes.

The behaviour of potassium in thermally treated biomass was examined by Devi et al. [63]. Under an oxygen atmosphere above $650{ }^{\circ} \mathrm{C}$, potassium changed from being predominantly in the $\mathrm{KOH} /$ $\mathrm{K}_{2} \mathrm{CO}_{3} / \mathrm{K}_{2} \mathrm{O}$ state to being dispersed as metal (initially as vapour) throughout the carbon matrix. This led to a rapid increase in comparative reaction rates for chars prepared above this temperature. A similar, but less dramatic effect could be expected with $\mathrm{H}_{2} \mathrm{O}$ or $\mathrm{CO}_{2}$ gasification.

Two types of bench-scale gasifier were tested in order to assess the degree of retention of metals in the char formed during the air gasification of bagasse [64]. In a fluidised bed, most of the metals were lost, evidently due to carryover with the fines. The loss was larger as the bed operation time was extended. With a cyclone gasifier, the short residence ensured that the metals exited continuously with the product char, so that $70 \%$ were retained. A thermodynamic calculation based on equilibrium compositions overpredicted the measured loss, which is common in this type of application with the minimum free energy technique.

A study by Leiser et al. examined the gasification of pulverised straw and corn stover in entrained flow with pure oxygen [65]. The trials resulted in $>99 \%$ burnout after $2 \mathrm{~s}$, with any potassium collected at $600{ }^{\circ} \mathrm{C}$ appearing as flyash, predominantly as potassium salts $\left(\mathrm{KOH}, \mathrm{KCl}\right.$ and $\left.\mathrm{K}_{2} \mathrm{SO}_{4}\right)$ in the sub-micron range. The loss from straw calculated from equilibrium thermodynamics is shown in Fig. 6. Also shown in the diagram is the increased retention afforded by the addition of small amounts of clay (kaolin).

For coals gasified at $1300{ }^{\circ} \mathrm{C}$, Bläsing et al. [66] showed that the level of loss of $\mathrm{K}$ and $\mathrm{Na}$ depended on their mode of occurrence i.e. the chemical environment of the elements in the fuel.

\section{Catalytic gasification studies}

\subsection{Alkali - alkaline earth metals}

The preferred catalysts for char gasification reactions are the alkali and alkaline earth metals (AAEM), which almost invariably dominate the natural ash compositions. Most gasification studies are carried out by TGA on small samples at slow heating rates. They generally involve one gaseous reactant at a time, so that the interactions at work in an operating gasifier are absent.

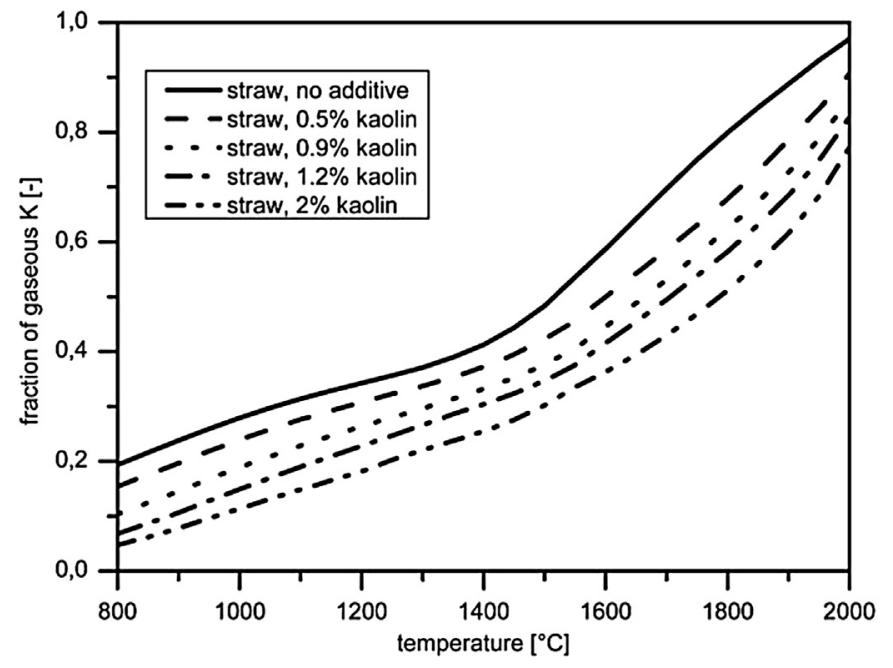

Fig. 6. Predicted loss of potassium from straw with gasification temperature [63]
Notable early work by McKee and colleagues involved an examination of the influence of a number of metals on carbon gasification, including the alkali metals [48], the alkaline earths [67], copper [68], and low-melting binary and ternary eutectics of the alkali metal halides, carbonates, and sulfates [69]. Lithium was found to be superior to potassium, especially with steam compared to carbon dioxide in the temperature range $700-900{ }^{\circ} \mathrm{C}$. The rates for $\mathrm{CO}_{2}$ between 700 and $1100{ }^{\circ} \mathrm{C}$ were found to be substantially increased on addition of small amounts of barium and strontium carbonates [67]. $\mathrm{CaCO}_{3}$ was much less active, and $\mathrm{MgCO}_{3}$ had only a slight effect on the kinetics. The catalytic process is interpreted in terms of a solid-state redox reaction as detailed in Section 2.2.

Low-melting binary and ternary eutectics of the alkali metal halides, carbonates, and sulfates are more effective lowtemperature catalysts for the $\mathrm{CO}_{2}$ and steam gasification of graphite and coal chars than the pure salt components [69]. The decreased melting point of the eutectic phase facilitates contact between the catalyst and the carbonaceous substrate.

The rate of carbon gasification with time is shown in Fig. 7 for two cedar-derived chars, one of which was doped with $1.4 \%$ potassium (25\% of the ash), and the other undoped [7]. The process conditions were $710{ }^{\circ} \mathrm{C}$ under $20 \%$ mole fraction steam at atmospheric pressure. The presence of the potassium significantly enhanced the reaction, with the time to 20\% burnoff falling from 75 to about $3 \mathrm{~min}$. A process is presented in which the doped wood is pyrolysed before being gasified with steam and the potassium is leached from the product for recycling.

From similar tests the kinetic data for char gasification are derived. A collection of data for the two char gasification reactions $\left(\mathrm{H}_{2} \mathrm{O}\right.$ and $\left.\mathrm{CO}_{2}\right)$ with a range of biomass materials is presented in Arrhenius form by both Di Blasi [28] and Klose and Wölki [70]. The catalytic effect of inherent minerals is not considered, although the degree of conversion is. There is general agreement between the two, although both sets of data are well spread. The results are better grouped for $\mathrm{CO}_{2}$ gasification than for steam; and steam is slightly more reactive. The mean activation energy is between 170 and $190 \mathrm{~kJ} \mathrm{~mol}^{-1}$, and the mean order of reaction for both processes is about 0.5 .

Arrhenius kinetic parameters have been determined for the $\mathrm{CO}_{2}$ gasification of chars (heat treatment at $1000{ }^{\circ} \mathrm{C}$ ) prepared from well-characterised samples of a hardwood, a softwood and a Montana lignite [71]. The effects of pre-pyrolysis addition of inorganic salts of the alkali, alkaline earth and transition metal groups to the wood samples were also determined. There was very little difference in the reactivity of chars prepared from the hardwood

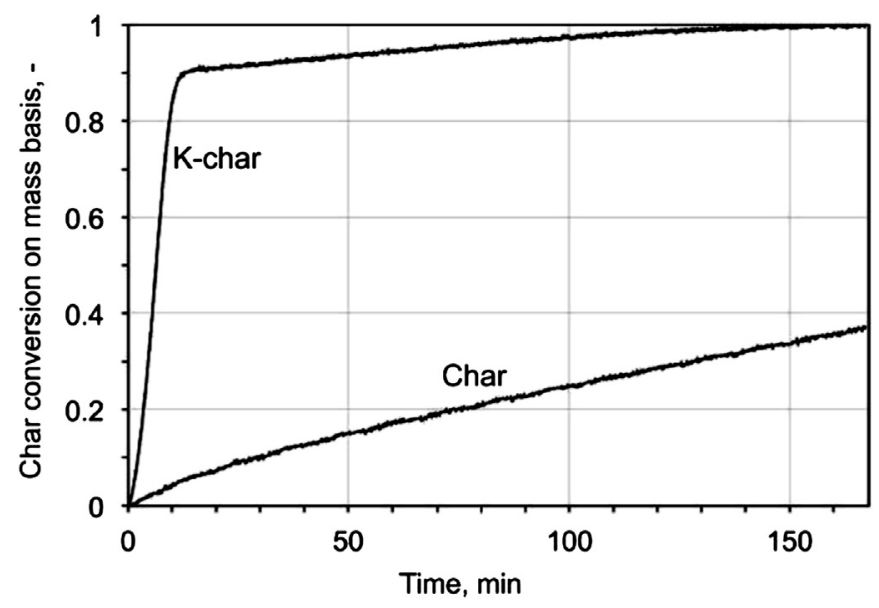

Fig. 7. Reaction history of cedar chars with steam, K-doped and undoped [7]. 
and the softwood after treatment with similar quantities of inorganic salts. The inorganic content of the lignite char was more than five times greater than that of cottonwood char, but its reactivity was similar. The carbonates of sodium and potassium were equally effective gasification catalysts. The transition metal salts were the most effective catalysts initially, but they lost their activity well before the gasification was complete.

Di Blasi discusses the reasons for the divergence of kinetic data, in terms of initial differences in char structure, its change during burnout, the catalytic effect of mineral matter and also mass transfer limitations. Variations in activation energy are explained by the operation of two parallel gasification reactions, one with a higher activation energy involving edge carbons, and a second lower one involving catalysed sites. The purer the carbon involved, the more likely it is to approach the higher value.

McKee and Chatterji [46] oxidised graphite with both $\mathrm{O}_{2}$ and $\mathrm{CO}_{2}$ in a TGA. For oxygen the relative activity rates were $\mathrm{Rb}, \mathrm{Cs}$, $\mathrm{Li}>\mathrm{K}>\mathrm{Na}$, whereas for $\mathrm{CO}_{2}$ the hierarchy was $\mathrm{Li}>\mathrm{Cs}, \mathrm{Rb}>\mathrm{K}>\mathrm{Na}$. Under carbon dioxide, catalytic reaction occurred only at temperatures in the vicinity of the carbonate fusion temperatures $\left(\mathrm{Li}=723, \mathrm{Na}=851, \mathrm{~K}=891, \mathrm{Rb}=837, \mathrm{Cs}=800^{\circ} \mathrm{C}\right)$. The carbon structure of the char investigated in that case would have the same influence on the other gasification reactions, namely with $\mathrm{H}_{2} \mathrm{O}$ and $\mathrm{CO}_{2}$. However, in view of the much slower intrinsic rates with the latter reactions, it is probable that any catalytic effect would be more pronounced with them.

Other early work on biomass samples of cellulose, holocellulose, Kraft lignin and Douglas fir by in 1984 established the importance of alkali catalysts [59]. They found that sodium, potassium and caesium carbonates were equally effective at typical gasification temperatures. The optimum concentration of sodium is claimed to be $3 \times 10^{-4}-1.5 \times 10^{-3} \mathrm{~mol}$ of alkali per gram of biomass. Pore diffusion and Knudsen diffusion effects were not present for Douglas fir char under the experimental conditions used. For the Mallee char tested by Asadullah [25], the dry ash content was only $0.9 \%$, with potassium the principal metal. Typical reaction rates at in air at $370{ }^{\circ} \mathrm{C}$ for chars prepared at $700{ }^{\circ} \mathrm{C}$ were $0.05 \mathrm{~g} \mathrm{~min}^{-1}$.

The performances of four widely different biomass types were compared by DeGroot et al. [72] by pyrolysis and subsequent gasification under $\mathrm{CO}_{2}$. The rates of char gasification varied over a 20 fold range, with potato pulp the most reactive, followed by sugar beet pulp, wheat straw and then sphagnum peat. The correlation of reactivity against AAEM contents was poor, but improved significantly when wheat straw was omitted. It was speculated that the high silica content of the straw sequestered the metals.

There is more information available on gasification reactions using coal chars than biomass chars, but the general principles should be common to both. The major difference in this context will be the much higher mineral matter content of the coals. For example, when a bituminous coal char was treated with steam using potassium carbonate catalyst, the reaction occurred significantly in a temperature range of $700-750{ }^{\circ} \mathrm{C}$, producing a hydrogen-rich gas with slight formation of carbon monoxide and virtually no formation of methane [73]. It was shown that the sodium content (inherent plus added) was directly proportional to the oxidation rate in air [38].

When the catalytic steam gasification of 34 coals ranging from anthracite to peat was conducted in a thermobalance at $850^{\circ} \mathrm{C}$ by Takarada et al. [74], it was found that $\mathrm{K}_{2} \mathrm{CO}_{3}$ was extremely effective, and its activity was almost independent of coal rank. On the other hand the performance of Ni was variable, depending on the coal type, and favoured low rank coals. The effectiveness of each depended on its dispersion throughout the char matrix.

A comparison of the effectiveness of various common metals for $\mathrm{CO}_{2}$ gasification was undertaken by Huang et al. [26], and some results given here as Fig. 8. Fir tree sawdust was doped with the metal solution, charred at $550^{\circ} \mathrm{C}$, and then gasified in a TGA under a ramping temperature regime. The study showed that the reactivity of the char was improved through the addition of metal catalysts in the order $\mathrm{K}>\mathrm{Na}>\mathrm{Ca}>\mathrm{Fe}>\mathrm{Mg}$. XRD (X-ray diffraction) analysis indicated that $\mathrm{Na}$ and $\mathrm{Ca}$ improved the formation of crystal structure, and that $\mathrm{Mg}$ enhanced the degree of carbon structure ordering. SEM (scaning electron microscopy) analysis showed that spotted activation centres were distributed on the surface of char samples impregnated with catalysts. The performance of the two alkali metals is virtually indistinguishable, even though the concentration of potassium is about half that of sodium ( $0.3 \mathrm{v} 0.7 \%$ ). Calcium, iron and magnesium, which were present at around $1 \%$, show some effectiveness as catalysts, but at a diminishing rate.

Link et al. [75] examined the reactivity towards $\mathrm{CO}_{2}$ of the chars derived from the pyrolysis of reed, pine pellets and Douglas fir wood chips. Their ashes contained from 3 to $5 \% \mathrm{~K}_{2} \mathrm{O}$ and 4 to $10 \%$ $\mathrm{CaO}$. The results of this study imply that the highly microporous structure together with a higher internal surface area and number of active sites and low Si content of the pine pellet char had a stronger impact on the gasification reactivity than the alkali/alkali earth metal contents of the Douglas fir wood chip and reed chars.

The relative reactivities during pyrolysis, char combustion and gasification of pine seed shells, olive husk and wood chips were examined by Senneca [76]. For all processes the olive husks were more reactive, probably due to the surface structure, although the differences in char gasification rates were not great. Catalysts increase reaction rates and lower the combustion temperature $[77,78]$, and generally lower the activation energy, but also compare [38].

Waste paper, sewage sludge and MSW (municipal solid waste) were studied for gasification reactivity with $\mathrm{CO}_{2}$ up to $950^{\circ} \mathrm{C}$, with the bulk of the reaction occurring above $800{ }^{\circ} \mathrm{C}$ [77]. Paper showed the greatest reactivity due to its large surface area. Acid-washing the biomass resulted in a significant fall in rate, and the temperature peak at $800-950{ }^{\circ} \mathrm{C}$ disappeared. The work was extended [78] by impregnating the biomass with alkali and alkaline earth metals at $10 \%$ by the addition of metal salts. They found the hierarchy of effectiveness for waste paper as $\mathrm{Li}_{2} \mathrm{CO}_{3}>\mathrm{K}_{2} \mathrm{CO}_{3}>\mathrm{CaCO}_{3}>\mathrm{Rb}_{2} \mathrm{CO}_{3}>$ $\mathrm{CaSO}_{4}>\mathrm{Cs}_{2} \mathrm{CO}_{3}>\mathrm{Na}_{2} \mathrm{CO}_{3}$. However, the orders were somewhat reversed with sewage sludge and MSW chars, although lithium was always among the best performers.

In a study of the $\mathrm{CO}_{2}$ gasification of cedar char, Mitsuoka et al. [57] found $\mathrm{K}$ and $\mathrm{Ca}$ to be active, but noted the inhibiting effect of $\mathrm{CO}$ with elevated $\mathrm{CO}_{2}$ concentrations. The effect of acid washing and the addition of extra potassium and calcium on the time to $t_{0.5}$

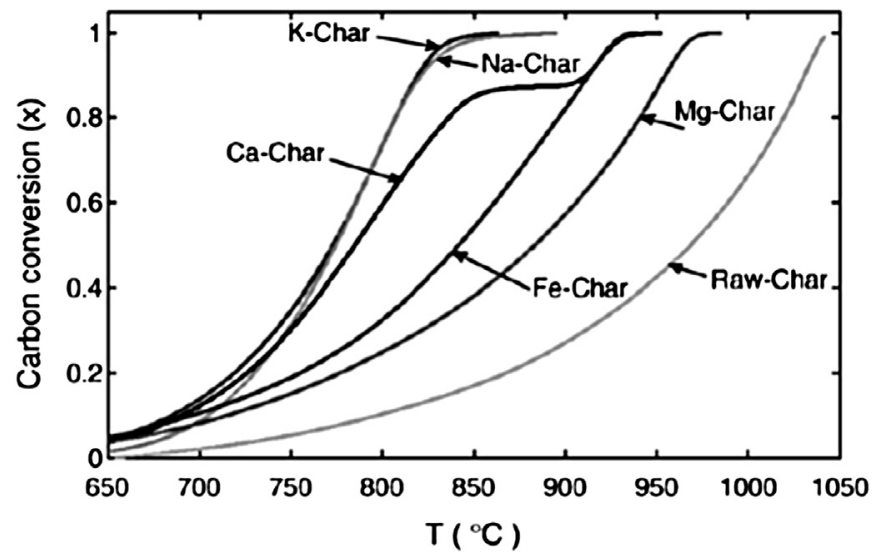

Fig. 8. Conversion of fir char with different catalysts under $100 \% \mathrm{CO}_{2}$ at $10{ }^{\circ} \mathrm{C} / \mathrm{min}$ temperature ramp [26] 
(time for half burnout) are depicted in Fig. 9. For the three samples - acid-washed, untreated and doped under the conditions tested, the calcium was slightly more effective.

Zhang [79] and Zhang et al. [80,81] tested 14 different biomass samples including sawdust, bark and some agricultural wastes by gasifying with $50 \mathrm{kPa}$ steam at $850^{\circ} \mathrm{C}$ chars which had been formed at $900^{\circ} \mathrm{C}$. Some of their reactivity measurements are reproduced as Fig. 10 [81], where the results fall into three groups. In Group I are those chars where $[\mathrm{K}]+[\mathrm{Na}]>[\mathrm{Ca}]$, and Group II where $[\mathrm{Ca}]>[\mathrm{K}]+[\mathrm{Na}]$. It is apparent that the inherent alkali metals are more effective than inherent calcium. Group III chars contained very high silica contents (rice husks and bagasse), such that alkali silicates were formed at low temperatures and their catalytic action was curtailed. A random pore model was successfully applied to describe burnout, with the two parameters related to potassium content.

The impregnation of wet biomass with calcium in a two-stage gasifier was studied [82] to determine the effect on conversion rate. Rodriguez-Mirasol et al. [83], and Tancredi et al. [84] gasified kraft-based lignin char with $\mathrm{CO}_{2}$ and found that the minerals in the ash, which constituted $1.5-3 \%$ of the dry matter, and was predominantly sodium, acted as an effective catalyst. As a consequence of the kraft source of the material, the sodium was well-dispersed and effective at low concentrations. The activation energy for chars prepared at various temperatures was around $230 \mathrm{~kJ} \mathrm{~mol}^{-1}$.

Food waste was simulated for gasification [85], but no analysis of the material was given. An increase in the steam gasification rate with char burnout was interpreted as a catalytic effect of the unspecified inorganic fraction. Chars prepared from grapefruit skins were studied by Marquez-Montesinos et al. [86] under both steam and $\mathrm{CO}_{2}$, in the raw and acid-washed condition. The difference in rates, and their continued increase with burnout, indicated a pronounced catalytic effect of the $15 \%$ ash content, with potassium the dominant inorganic.

The catalytic effect of ash on the initial gasification rate of beech wood char with $20 \%$ steam at $1200 \mathrm{~K}$ was shown by Mermoud et al. $[87,88]$ to be directly proportional to its concentration. The ash consisted mainly of calcium (45\%) and potassium (38\%). The effect of pyrolysis heating rate on char properties was also examined; rapid heating resulted in a more porous char. For all cases the apparent reaction rates increased with burnout, up to a factor of 20 times for the less dense chars. In keeping with conclusions relating to the char $-\mathrm{O}_{2}$ [89] and char-NO reactions [90], it appears that micropores do not participate in the char $-\mathrm{H}_{2} \mathrm{O}$ reaction.

In the case of coal char, it was found that calcium assisted gasification in steam by preventing potassium (as $\mathrm{K}_{2} \mathrm{CO}_{3}$ ) from

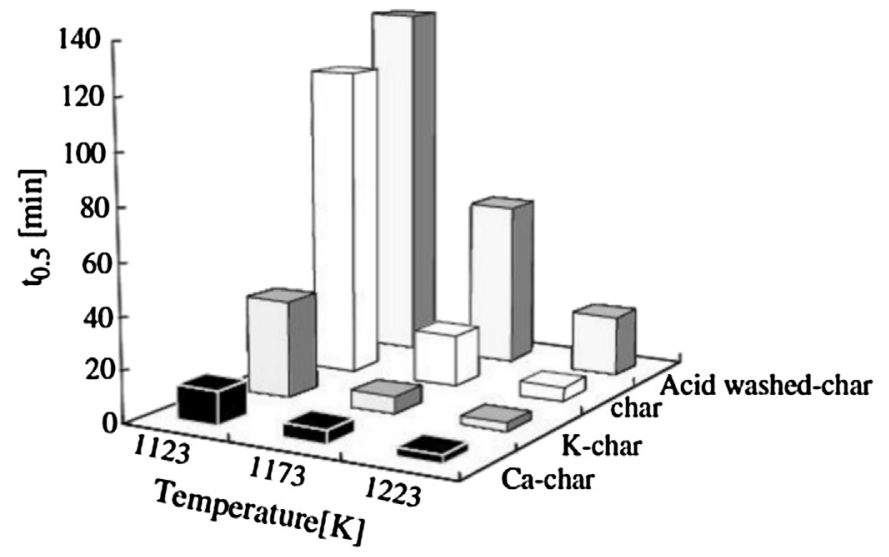

Fig. 9. Half-burnout time for Japanese cypress char in $\mathrm{CO}_{2}$ :acid-washed char: $\mathrm{Ca}=0.11 \%, \mathrm{~K}=0.014 \%$; char $0.24 \%$ and $0.15 \%$; doped $2.4 \%$ and $2.4 \%$ [57].

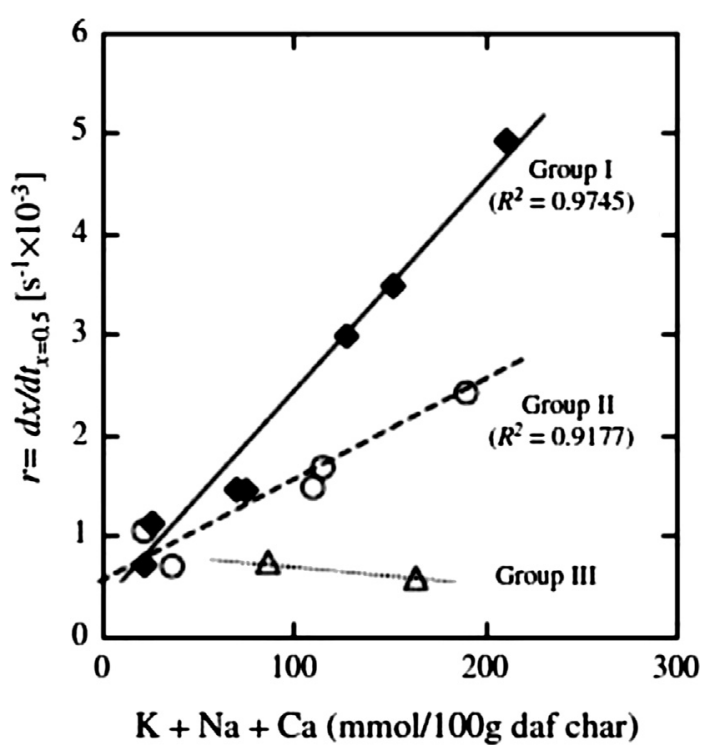

Fig. 10. Reactivity towards steam of 14 biomass chars with respect to the AAEM content [79] Group I: [K] + [Na] > [Ca]; Group II: [Ca] > [K] + [Na]; Group III: high $\left[\mathrm{SiO}_{2}\right]$.

being deactivated as a catalyst [91]. A synergistic effect was operating between the two, with a mixed carbonate $\mathrm{K}_{2} \mathrm{Ca}\left(\mathrm{CO}_{3}\right)_{2}$ being identified as the active species.

During entrained flow, pressurised gasification in $\mathrm{CO}_{2}$ of sugar cane bagasse, the amorphous plant silica structures were found to remain physically intact, but chemically altered in the presence of other inorganic species [92]. The resulting crystalline silicates were mesoporous (with surface areas of the order of $20 \mathrm{~m}^{2} \mathrm{~g}^{-1}$ ) and contributed to much of the otherwise limited pore volume present in the residual chars. Progressive sintering of the silicates appeared to trap coke deposits in the pore network. As a result, the ash residuals showed significant organic contents, even after extensive additional oxidation in air.

A pilot scale gasification study of three biomass types with steam in a two-step process involving pyrolysis and then gasification of char is reported [93]. The recycling of product ash i.e. Ca and $\mathrm{K}$ to the second stage gasification reactor induced a significant increase in carbon conversion. Zhu et al. [94] suggest that straw be added to coal char to act as a cheap catalyst during gasification, and demonstrated a doubling in reaction rate with a 20:80 straw:coal mixture of chars.

\subsection{Transition metals}

Gasification is typically conducted over AAEMs, but supported noble metal catalysts show promise. The current objective now is to make these processes cost-competitive in today's markets. The known processes yield a complex mixture of products, leading to problematic upgrading and separation of components. An emerging technique is to integrate hydrolysis, liquefaction or pyrolysis with hydrogenation over multifunctional solid catalysts. Promising catalysts might be supported transition metal catalysts and zeolite-related materials, heteropolyacids and oxides. There still exist technological barriers that need to be overcome.

A number of transition metals, namely $\mathrm{Cu}, \mathrm{Ni}, \mathrm{Co}$, Fe and Ca were ion-exchanged onto CMC (carboxymethylcellulose) and pyrolysed at temperatures between 300 and $1000{ }^{\circ} \mathrm{C}$ [95]. XRD diffraction studies indicated that the metals existed on the char as oxide, metal or carbide, depending on the temperature. The application of Ellingham diagrams viz a plot of free energy change for a given 
reaction against temperature confirmed the results. The generallyaccepted mechanism for catalysis involving redox does not seem to apply in this situation. An alternative cycle is proposed, involving the formation of weakly bound $\mathrm{O}$ atoms on the catalyst, which desorb and are transferred to the carbon surface.

The effect of $\mathrm{Fe}, \mathrm{Co}$ and $\mathrm{Ni}$ on gasification under oxygen at 300$550{ }^{\circ} \mathrm{C}$, and $\mathrm{CO}_{2}$ at $700-800{ }^{\circ} \mathrm{C}$ was studied by Gallagher and Harker [96], who found that their effectiveness depends on the liberation of free metal, which then becomes incorporated as a complex into the carbon structure. A study of $\mathrm{Ni}$, Co and Fe catalysis of $\mathrm{CO}_{2}$ gasification [97] found that nickel and cobalt performed better than iron, but conversions were limited by catalyst deactivation. The texture of the carbon determined the extent of dispersion of the catalyst, and hence its efficacy.

Carbons were prepared by Marsh and Adair from furfuryl alcohol doped with metals, and then gasified with a range of gases, including $\mathrm{CO}_{2}, \mathrm{~N}_{2} \mathrm{O}$ and $\mathrm{O}_{2}$ [98]. The relative reaction rates were found to decrease in the order $\mathrm{Ni}>\mathrm{Co}>\mathrm{Cu}>\mathrm{Ag}>\mathrm{Fe}>\mathrm{Ca}$. The activation energies fell into two sections, decreasing with temperature and also concentration of nickel. The mobility of small catalyst is considered to facilitate the formation of non-stoichiometric $\mathrm{C}-\mathrm{O}-\mathrm{M}$ bridges.

Matas Güell et al. gasified the carbon formed from the charring of a bio-oil produced from wood with both $\mathrm{CO}_{2}$ and steam over a cerium/zirconium catalyst on a silica base [99]. The char was produced either internally with the catalyst pores by pyrolysis of the absorbed oil, or physically mixed with pre-prepared char. The catalyst performed well in both situations, although as one would anticipate from the intimate contact resulting from internal preparation, superior performance was found in this case. They comment that $\mathrm{CeO}_{2}$ has excellent oxygen exchange capacity involving redox changes between $\mathrm{Ce}^{4+}$ and $\mathrm{Ce}^{3+}$, and has the ability to activate $\mathrm{H}_{2} \mathrm{O}$ and $\mathrm{CO}_{2}$. In addition, $\mathrm{CO}_{2}$ will reoxidise reduced forms of $\mathrm{CeO}_{2}$ at temperature below $350^{\circ} \mathrm{C}$. The $\mathrm{Ce} / \mathrm{Zr}$ formulations do not catalyse the methanation reaction with carbon, and thus favour high hydrogen yields, in contrast to AAEM and Ni-based catalysts.

Early work on the efficacy of iron and cobalt carbonyls as catalysts was reviewed and reported in 1962 [100]. More recently, further observations were made [101] which showed that the use of $0.5 \mathrm{wt} \%$ of $\mathrm{Fe}$ added as $\mathrm{Fe}(\mathrm{CO})_{5}$ resulted in an increase in gasification of carbon from $39 \%$ to $82 \%$. The reactivity was attributed to the ultra-dispersed nature of the catalyst. Many catalytic reactions are reported to be mediated by iron based compounds [102] and particularly low oxidation state transition metals [103]. Gas phase reactions $\left(\mathrm{CO}+2 \mathrm{H}_{2}=-\mathrm{CH}_{2}-+\mathrm{H}_{2} \mathrm{O}\right)$ are promoted by metal carbonyl systems derived from simple volatile mononuclear carbonyls such as $\mathrm{Fe}(\mathrm{CO})_{5}$ and $\mathrm{M}(\mathrm{CO})_{6}(\mathrm{M}=\mathrm{Cr}$, Mo, and $\mathrm{W})$.

An interesting feature of metal carbonyl chemistry involves the formation of clusters or multi-metal complexes with different reactivity [104]. Clusters are found in heterogeneous catalysis, and organic molecules may interact with more than one metal in clusters. Because of the high electron density at the metal center due to ligand back bonding, the zero-valent electrophilic reagent $\mathrm{H}+$ can easily get inserted in the cluster by forming a metal hydride bridge. Clusters can be used to catalyse hydrogenation reactions using water as a substrate, and some clusters can approach the size of colloids. Heterogeneous systems are made by supporting metal clusters on metal oxides, zeolites or carbon.

Organometallic complexes are versatile because functional ligand molecules such as hydrogen, carbon monoxide and alkenes can form bonds with metals or insert in metal-metal bonds. It is claimed that the water gas shift reaction appears to involve an associative mechanism with a metallocarboxylate intermediate $\left[(\mathrm{CO})_{4} \mathrm{Fe}-\mathrm{CO}_{2} \mathrm{H}\right]-[105]$. By studying the conversion of copper- polluted fir sawdust, Liu et al. [106] have shown that copper can effectively catalyse the thermo-decomposition of biomass. The use of cerium-impregnated zirconia has been examined to facilitate the gasification of residual char produced by the evaporation of bio-oil. It provided high reactivity, but was effective only when the char was generated within the catalyst pores to ensure good contact.

The knowledge accumulated by organometallic chemists has not yet been applied to pyrolytic processes. More advances in this field are expected in the near future, particularly because heavymetal polluted biomass derived from phytoremediation or biosorption are becoming widespread. The influence of the metal cocktails present in such wastes will need examination prior to treatment. Metals present in waste may promote or inhibit reaction kinetics and a proper combination of selected wastes to be mixed may resolve potential conflicts in gasification.

\section{Catalysis of carbon gasification by oxygen}

The most promising technology for gasifying biomass appears to be a two stage process, such as the installations at Güssing, Vermont and Ulm. Any catalyst added to facilitate gasification in the first stage will probably be carried over with the char into the second vessel. Its effect on the oxidation of the carbon in the second bed therefore assumes some importance in the overall performance of the system. In addition, the char in the primary bed will be attacked by residual oxygen as well as $\mathrm{CO}_{2}$ and $\mathrm{H}_{2} \mathrm{O}$, so that comments on this aspect are also called for.

The rate of oxidation of carbon by oxygen is approximately three orders of magnitude faster than the action of water vapour and carbon dioxide. In a single stage gasifier, any oxygen introduced will be consumed mostly in the gas phase, reacting with volatile components which form the bulk of the products from the biomass. The char remaining will be exposed mainly to steam and $\mathrm{CO}_{2}$ as gasifying agents, with very low concentrations of oxygen in a wellmixed bed.

The study of the catalytic oxidation of carbon has generated a huge body of literature, particularly following the introduction of regenerative filters for the control of diesel particulates e.g. Refs. [107-109]. Any catalysts used generally involve cerium incorporated into the matrix of an extruded cordierite or mullite filter. Readers are referred to Ref. [110] as a summary of the use of transition metals in that application. As the catalysts likely to be employed for biomass gasification are members of the AAEM family, and not those used in the motor industry, the discussion will be restricted mostly to the former.

A major difference between the behaviour of metallic catalysts on carbon under oxidising as opposed to reducing conditions is the mobility of small particles across the surface. It was found [111] that larger copper oxide particles were immobile, but smaller ones in the 1-5 $\mu \mathrm{m}$ range moved rapidly on the basal plane of graphite, and cut channels by removing surface layers of carbon. In contrast silver, cobalt and tantalum displayed a rotary motion [112]. The effect does not appear with $\mathrm{CO}_{2}$ or $\mathrm{H}_{2} \mathrm{O}$ atmospheres.

As reported above [46] when graphite was gasified with both $\mathrm{O}_{2}$ and $\mathrm{CO}_{2}$ in a TGA, the relative activity rates under oxygen were $\mathrm{Rb}$, $\mathrm{Cs}, \mathrm{Li}>\mathrm{K}>\mathrm{Na}$, whereas for $\mathrm{CO}_{2}$ the hierarchy was only slightly different as $\mathrm{Li}>\mathrm{Cs}, \mathrm{Rb}>\mathrm{K}>\mathrm{Na}$. McKee favours the oxygen-transfer mechanism, as opposed to the electron-transfer mechanism, to explain the catalytic activity, and has received support from Matas Güell and others.

An illuminating series of studies of the catalytic action of some metals and their dispersion in char during oxygen gasification was undertaken by Devi et al. [113-115], using carboxymethylcellulose (CMC) char. They found that the temperature at which the chars were prepared influenced the chemical form of the metal, with 
potassium being significantly affected. A temperature jump in reactivity occurred around the Tammann temperature ( $\sim 715 \mathrm{~K})$, in a similar fashion to those found with copper, calcium and nickel catalysts.

The Tammann temperature is the minimum temperature at which a solid will undergo solid interaction, probably because of a diminution of rigidity (increase in plasticity). It is given as a fraction of the absolute melting temperature; for ionic solids it is about 0.3, for surface diffusion and 0.5 for bulk diffusion. Baker [116] identified a good relationship of 0.51 between the mobility temperature of common catalysts on a carbon surface and their bulk melting temperature.

It is significant that this jump in rate does not seem to occur with $\mathrm{CO}_{2}$ gasification, see for example, Fig. 1 where the traces cover the same temperature range as the tests by Devi et al. It could be concluded that the metal species which migrate across the surface to produce the temperature jump with oxygen do not form under a $\mathrm{CO}_{2}$ atmosphere. Indeed McKee notes that for potassium, which exhibits this effect most prominently, the carbonate is the exclusive form at temperatures below its boiling point [48].

Devi et al. propose that at temperatures below about $923 \mathrm{~K}$ (the boiling point of metallic potassium), the active species is a $\mathrm{K}_{2} \mathrm{O}$ / $\mathrm{K}_{2} \mathrm{CO}_{3} / \mathrm{KOH}$ mixture, while at higher temperatures the potassium vaporises as metal and then interacts with the carbon surface to give a much more active catalytic system. The system is labelled as a K-complex, and it is suggested that it is distributed on a nanoscale, below the XRD size limit of $\sim 4 \mathrm{~nm}$.

Similarly, Kannan and Richards [31] found that when the chars from ten different types of biomass were gasified with oxygen at $700{ }^{\circ} \mathrm{C}$, the rates of gasification showed a linear dependence on the combined molar concentration of the dominant metals (potassium and calcium). For two samples, it was concluded that the catalytic effect of $\mathrm{K}$ was reduced by reaction with silica to form silicate during pyrolysis. Copper was found to be active during the air gasification of CMC char [113], with the rate increase associated with a decrease in activation energy, and increased catalyst mobility.

X-ray diffraction (XRD) and environmental SEM (ESEM (environmental scaning electron microscopy)) techniques were used [117] to study the oxidation of an activated charcoal catalysed by $\mathrm{MoO}_{3}$ and $\mathrm{V}_{2} \mathrm{O}_{5}$, their eutectic alloy and the binary mixture with the eutectic composition. The XRD and ESEM observations revealed that the compounds were reduced to lower oxides, namely $\mathrm{MoO}_{2}$ and $\mathrm{V}_{6} \mathrm{O}_{13}$ respectively. A synergy was observed between the components of the eutectic mixture.

The catalysis of the $\mathrm{C}-\mathrm{O}$ reaction by 7 Groups $5 \mathrm{~B}$ and $6 \mathrm{~B}$ metal carbides and oxides was studied by Yang and Wong [118]. Among the catalysts used in the study, only $\mathrm{MoO}_{3}$ followed the wellestablished mode of channelling, while all others catalysed the reaction at the edges of the etch pits which were distant from the catalyst by apparently a long-range action. Since the experiments were performed near the Tammann temperature, it was assumed that small mobile clusters were responsible.

A comparison of the effect by potassium and calcium on the air gasification of lignite coal/char [119] found that potassium achieves relatively high catalytic activity by chemical interaction with the carbon, no matter how it is added to the lignite or its char. Deactivation of the catalytic potassium is brought about by interaction with inherent aluminosilicates. However, deactivation of calcium is related to its sintering via crystallite growth.

\section{Conclusion}

The potassium, sodium and calcium inherent in biomass chars are among the most effective catalysts for gasification by steam and carbon dioxide. The free metals are released and vapourise at higher temperatures, thus becoming finely dispersed throughout the carbon matrix. Many researchers postulate the formation of active non-stoichiometric carbon/potassium surface complexes. Carbon monoxide, hydrogen and tars act to inhibit the reaction by occupying active sites. Any silica or alumina present in the ash tends to react with the AAEM metals and negate their catalytic effect. Transition metals are effective for gasification with oxygen. Under oxygen the alkali metals become mobile around their Tammann temperatures, leading to a jump in reaction rate. More research may identify other metallic species beneficial for biomass conversion, although some elements present in waste biomass may prevent char gasification by poisoning catalysts.

\section{References}

[1] Nashawi IS, Malallah A, Al-Bisharah $\mathrm{M}$. Forecasting world crude oil production using multicyclic Hubbert model. Energy Fuels 2010;24:1788-800.

[2] http://nzic.org.nz/ChemProcesses/energy; 2008VII-energy-C-Kapuni natural gas-7.

[3] Wang L, Weller CL, Jones DD, Hanna MA. Contemporary issues in thermal gasification of biomass and its application to electricity and fuel production. Biomass Bioenergy 2008;32:573-81.

[4] Schnoor JL. Cellulosic biofuels disappoint. Environ Sci Technol 2011;45:7099.

[5] Baker EG, Mudge LK. Mechanisms of catalytic biomass gasification. J Anal Appl Pyrolysis 1984;6:285-97.

[6] Fushimi C, Wada T, Tsutsumi A. Inhibition of steam gasification of biomass char by hydrogen and tar. Biomass Bioenergy 2011;35:179-85.

[7] Sueyasu T, Oike T, Mori A, Kudo S, Norinaga K, Hayashi J. Simultaneous steam reforming of tar and steam gasification of char from the pyrolysis of potassium-loaded woody biomass. Energy Fuels 2012;26:199-208.

[8] Murakami T, Xu G, Suda T, Matsuzawa Y, Tani H, Fujimori H. Some process fundamentals of biomass gasification in dual fluidized bed. Fuel 2007;86: 244-55.

[9] Chaudhari ST, Bej SK, Bakhshi NN, Dalai AK. Steam gasification of biomassderived char for the production of carbon monoxide-rich synthesis gas. Energy Fuels 2001;15:736-74.

[10] Di Blasi C. Modeling chemical and physical processes of wood and biomass pyrolysis. Prog Energy Combust Sci 2008;34:47-90.

[11] Bridgwater AV. The technical and economic feasibility of biomass gasification for power generation. Fuel 1995; 14:631-53.

[12] Xie Q Kong S, Liu Y, Zeng H. Syngas production by two-stage method of biomass catalytic pyrolysis and gasification. Bioresour Technol 2012;110: 603-9.

[13] Kramreiter $\mathrm{R}$, Url M, Kotik J, Hofbauer $\mathrm{H}$. Experimental investigation of a $125 \mathrm{~kW}$ twin-fire fixed bed gasification pilot plant and comparison to the results of a $2 \mathrm{MW}$ combined heat and power plant (CHP). Fuel Process Technol 2008;89:90-102.

[14] Kaushal P, Pröll T, Hofbauer H. Application of a detailed mathematical model to the gasifier unit of a dual fluidized gasification plant. Biomass Bioenergy 2011;35:2491-8

[15] Baratieri M, Pieratti E, Nordgreen T, Grigiante M. Biomass gasification with dolomite as catalyst in a small fluidized bed experimental and modelling analysis. Waste Biomass Valoriz 2010;1:283-91.

[16] Li J, Xiao B, Yan R, Xu X. Development of a supported tri-metallic catalyst and evaluation of the catalytic activity in biomass steam gasification. Bioresour Technol 2009;100:5295-300.

[17] Rapagna S, Jand N, Kiennemann A, Foscolo PU. Steam-gasification of biomass in a fluidised bed of olivine particles. Biomass Bioenergy 2000;19:187-97.

[18] Rapagnà S, Virginie M, Gallucci K, Courson C, Di Marcello M, Kiennemann A, et al. Fe/olivine catalyst for biomass steam gasification: preparation, characterization and testing at real process conditions. Catal Today 2011;176:163-8.

[19] Hurley S, $\mathrm{Li} \mathrm{H}, \mathrm{Xu}$ C. Effects of impregnated metal ions on air $/ \mathrm{CO}_{2}$-gasification of woody biomass. Bioresour Technol 2010;101:9301-7.

[20] Abu El-Rub ZE, Bramer EA, Brem G. Experimental comparison of biomass chars with other catalysts for tar reduction. Fuel 2008;87:2243-52.

[21] Di Felice L, Courson C, Janda N, Galluccia K, Foscolo PU, Kiennemann A. Catalytic biomass gasification: simultaneous hydrocarbons steam reforming and $\mathrm{CO}_{2}$ capture in a fluidised bed reactor. Chem Eng J 2009;154:375-83.

[22] Han J, Kim H. The reduction and control technology of tar during biomass gasification/pyrolysis: an overview. Renew Sustain Energy Rev 2008;12: 397-416.

[23] Shen Y, Yoshikawa K. Recent progresses in catalytic tar elimination during biomass gasification or pyrolysis - a review. Renew Sustain Energy Rev 2013;21:371.

[24] Yung MM, Jablonski WS, Magrini-Bair KA. Review of catalytic conditioning of biomass-derived syngas. Energy Fuels 2009;23:1874-87.

[25] Asadullah M, Zhang S, Min Z, Yimsiri P, LiC- Z. Effects of biomass char structure on its gasification reactivity. Bioresour Technol 2010;101:7935-43.

[26] Huang Y, Yin X, Wu C, Wang C, Xie J, Zhou Z. Effects of metal catalysts on $\mathrm{CO}_{2}$ gasification reactivity of biomass char. Biotechnol Adv 2009;27:568-72. 
[27] Bayarsaikhana B, Sonoyama N, Hosokai S, Shimada T. Inhibition of steam gasification of char by volatiles in a fluidized bed under continuous feeding of a brown coal. Fuel 2006;85:340-9.

[28] Di Blasi C. Combustion and gasification rates of lignocellulosic chars. Prog Energy Combust Sci 2009;35:121-40.

[29] Couhert C, Commandré J-M, Salvador S. Is it possible to predict gas yields of any biomass after rapid pyrolysis at high temperature from its composition in cellulose, hemicellulose and lignin? Fuel 2009;88:408-17.

[30] Worasuwannarak N, Sonobe T, Tanthapanichakoon W. Pyrolysis behaviours of rice straw, rice husk, and corncob by TG-MS technique. J Anal Appl Pyrolysis 2007; $78: 265-71$

[31] Kannan MP, Richards GN. Potassium catalysis in air gasification of cellulosic chars. Fuel 1990;69:999-1006.

[32] DeGroot WF, Richards GN. Influence of pyrolysis conditions and ionexchanged catalysts on the gasification of cottonwood chars by carbon dioxide. Fuel 1988;67:352-60.

[33] Hawley MC, Boyd M, Anderson C, De Vera A. Gasification of wood char and effects of intraparticle transport. Fuel 1982;62:213-6.

[34] Backreedy RI, Jones JM, Pourkashanian M, Williams A. Modelling the reaction of oxygen with coal and biomass chars. Proc Combust Inst 2002;29:415-22.

[35] Marsh H. Introduction to carbon science. Butterworths; 1989. p. 52.

[36] Wu H, Yip K, Tian F, Xie Z, Li C- Z. Evolution of char structure during the steam gasification of biochars produced from the pyrolysis of various Mallee biomass components. Ind Eng Chem Res 2009;48:10431-8.

[37] Li X, Wu H, Hayashi J, Li C-Z. Volatilisation and catalytic effects of alkali and alkaline earth metallic species during the pyrolysis and gasification of Victorian brown coal. Part VI. Further investigation into the effects of volatile-char interactions. Fuel 2004;83:1273-9.

[38] Wu H, Hayashi J, Chiba, Takarada, Li C-Z. Volatilisation and catalytic effects of alkali and alkaline earth metallic species during the pyrolysis and gasification of Victorian brown coal. Part V. Combined effects of Na concentration and char structure on char reactivity. Fuel 2004;83:23-30.

[39] Keowna DM, Hayashib J, Li C. Drastic changes in biomass char structure and reactivity upon contact with steam. Fuel 2008;87:1127-32.

[40] Fahmi R, Bridgwater AV, Darvell LI, Jones JM, Yates N, Thain S, et al. The effect of alkali metals on combustion and pyrolysis of Lolium and Festuca grasses, switchgrass and willow. Fuel 2007;86:560-1569.

[41] Sonobe T, Worasuwannarak N. Kinetic analyses of biomass pyrolysis using the distributed activation energy model. Fuel 2008;87:414-21.

[42] Hodge EM, Roberts DG, Harris DJ, Stubington JF. The significance of char morphology to the analysis of high-temperature char- $\mathrm{CO}_{2}$ reaction rates. Energy Fuels 2010;24:100-7.

[43] Cetin E, Moghtaderi B, Gupta R, Wall TF. Biomass gasification kinetics: influence of pressure and char structure. Combust Sci Technol 2005;177:765-91.

[44] Moulijn JA, Cerfontain MB, Kapteijn F. Mechanism of the potassiumcatalysed gasification of carbon in $\mathrm{CO}_{2}$. Fuel 1984;63:1043-7.

[45] Moilanen A, Nasrullah M, Kurkela E. Feedstock type and process parameter on achieving the total carbon conversion in the large scale fluidized bed gasification of biomass. Environ Prog Sustain Energy 2009;28:355-9.

[46] McKee DW, Chatterji D. The catalytic effect of alkali metal carbonates and oxides in graphite oxidation reactions. Carbon 1975;13:381-90.

[47] Kajita M, Kimura T, Norinaga K, Li C-Z, Hayashi J. Catalytic and noncatalytic mechanisms in steam gasification of char from the pyrolysis of biomass. Energy Fuels 2010;24:108-16.

[48] McKee DW. Gasification of graphite in carbon dioxide and water vapour the catalytic effect of alkali metal salts. Carbon 1982;20:59-66.

[49] Huang Z, Zhang J, Zhao Y, Zhang H, Yue G, Suda T, et al. Kinetic studies of char gasification by steam and $\mathrm{CO}_{2}$ in the presence of $\mathrm{H}_{2}$ and $\mathrm{CO}$. Fuel Process Technol 2010;91:843-7.

[50] Roberts DG, Harris DJ. High-pressure char gasification kinetics: CO inhibition of the $\mathrm{C}-\mathrm{CO}_{2}$ reaction. Energy Fuels 2012;26:176-84.

[51] Delannay F, Tysoe WT, Heinemann H, Somarji GA. The role of $\mathrm{KOH}$ in the steam gasification of graphite: identification of the reaction steps. Carbon 1984;22:401-7.

[52] Yokoyama S, Tanaka K, Toyoshima I, Miyahara K, Yoshida K, Tashiro J. X-ray photoelectron spectroscopic study of the surface of carbon doped with potassium carbonate. Chem Lett 1980;9:599-602.

[53] Wigmans T, Haringa H, Moulijn JA. Nature, activity and stability of active sites during alkali metal carbonate-catalysed gasification reactions of coal char. Fuel 1983;62:185-9.

[54] Hüttinger KJ, Minges R. Influence of the catalyst precursor anion in catalysis of water vapour gasification of carbon by potassium: 1 . Activation of the catalyst precursors. Fuel 1986;65:1112-21.

[55] Hüttinger KJ, Minges R. Influence of the catalyst precursor anion in catalysis of water vapour gasification of carbon by potassium: 2. Catalytic activity as influenced by activation and deactivation reactions. Fuel 1986;65:1122-8.

[56] Gea G, Sánchez JL, Murillo MB, Arauzo J. Kinetics of $\mathrm{CO}_{2}$ gasification of alkaline black liquor from wheat straw. Influence of $\mathrm{CO}$ and $\mathrm{CO}_{2}$ concentrations on the gasification rate. Ind Eng Chem Res 2004;43:3233-41.

[57] Mitsuoka K, Hayashi S, Amano H, Kayahara K, Sasaoaka E, Uddin MA. Gasification of woody biomass char with $\mathrm{CO}_{2}$ : the catalytic effects of $\mathrm{K}$ and $\mathrm{Ca}$ species on char gasification reactivity. Fuel Process Technol 2011;92:26-31.

[58] Hosokai S, Kumabe K, Ohshita M, Norinaga K, Li C-Z, Hayashi J-I. Mechanism of decomposition of aromatics over charcoal and necessary condition for maintaining its efficiency. Fuel 2008;87:2914-22.
[59] Elliott DC, Hallen RT, Sealock Jr J. Alkali catalysis in biomass gasification. J Anal Appl Pyrolysis 1984;6:299-316.

[60] Kowalski T, Ludwig C, Wokaun A. Qualitative evaluation of alkali release during the pyrolysis of biomass. Energy Fuels 2007;21:3017-22.

[61] Li X, Hayashi J, Li C-Z. Volatilisation and catalytic effects of alkali and alkaline earth metallic species during the pyrolysis and gasification of Victorian brown coal. Part VII. Raman spectroscopic study on the changes in char structure during the catalytic gasification in air. Fuel 2006;85: 1509-17.

[62] Jiang L, Hu S, Xiang S, Su S, Sun L, Xu K, et al. Release characteristics of alkali and alkaline earth metallic species during biomass pyrolysis and steam gasification process. Bioresour Technol 2012;116:278-84.

[63] Devi TG, Kannan MP, Abduraheem VP. Jump in the air gasification rate of potassium-doped cellulosic chars. Fuel Process Technol 2010;91: 1826-31.

[64] Gabra M, Nordin A, Öhman M, Kjellström B. Alkali retention/separation during bagasse gasification: a comparison between a fluidised bed and a cyclone gasifier. Biomass Bioenergy 2001;21:461-76.

[65] Leiser S, Cieplik MK, Smit R. Slagging behavior of straw and corn stover and the fate of potassium under entrained-flow gasification conditions. Energy Fuels 2013;27:318-26.

[66] Bläsing M, Müller M. Release of alkali metal, sulfur, and chlorine species during high-temperature gasification of coal and coal blends in a drop tube reactor. Energy Fuels 2012;26:6311-5.

[67] McKee DW. Catalytic effects of alkaline earth carbonates in the carboncarbon dioxide reaction. Fuel 1980;59:308-14.

[68] McKee DW. Metal oxides as catalysts for the gasification of graphite. Carbon 1970;8:623-6.

[69] McKee DW, Spiro CL, Kosky PG, Lamby EJ. Eutectic salt catalysts for graphite and coal char gasification. Fuel 1985;64:805-9.

[70] Klose W, Wölki M. On the intrinsic rate of biomass char gasification with carbon dioxide and steam. Fuel 2005;84:885-92.

[71] De Groot WF, Shafizadeh F. Kinetics of gasification of Douglas fir and cottonwood chars by carbon dioxide. Fuel 1984;63:210-6.

[72] DeGroot WF, Kannan MP, Richards GN, Theander O. Gasification of agricultural residues (biomass): influence of inorganic constituents. J Agric Food Chem 1990;38:320-3.

[73] Wang J, Jiang M, Yao Y, Zhang Y, Cao J. Steam gasification of coal char catalyzed by $\mathrm{K}_{2} \mathrm{CO}_{3}$ for enhanced production of hydrogen without formation of methane. Fuel 2009;88:1572-9.

[74] Takarada T, Tamai Y, Tomita A. Effectiveness of $\mathrm{K}_{2} \mathrm{CO}_{3}$ and $\mathrm{Ni}$ as catalysts in steam gasification. Fuel 1986;65:679-83.

[75] Link S, Arvelakis S, Hupa M, Yrjas P, Külaots I, Paist A. Reactivity of the biomass chars originating from reed, Douglas fir, and pine. Energy Fuels 2010;24:6533-9.

[76] Senneca O. Kinetics of pyrolysis, combustion and gasification of three biomass fuels. Fuel Process Technol 2007;88:87-97.

[77] Vamvuka D, Karouki E, Sfakiotaki S. Gasification of waste biomass chars by carbon dioxide via thermogravimetry. Part I: effect of mineral matter. Fue 2011;90:1120-7.

[78] Vamvuka D, Karouki E, Sfakiotaki S, Salatino P. Gasification of waste biomass chars by carbon dioxide via thermogravimetry-effect of catalysts. Combust Sci Technol 2012;1:64-77.

[79] Zhang W. Automotive fuels from biomass via gasification. Fuel Process Technol 2010;91:866-76.

[80] Zhang Y, Ashizawa M, Kajitani S. Calcium loading during the dewatering of wet biomass in kerosene and catalytic activity for subsequent char gasification. Fuel 2008;87:3024-30.

[81] Zhang Y, Ashizawa M, Kajitani S, Miura K. Proposal of a semi-empirical kinetic model to reconcile with gasification reactivity profiles of biomass chars. Fuel 2008;87:475-81.

[82] Xu G, Murakami T, Suda T, Tani H, Mito Y. Efficient gasification of wet biomass residue to produce middle caloric gas. Particuology 2008;6:376-82.

[83] Rodriguez-Mirasol J, Cordero T, Rodriguez JJ. $\mathrm{CO}_{2}$ reactivity of eucalyptus kraft lignin chars. Carbon 1993;31:53.

[84] Tancredi N, Cordero T, Mirasol JR, Juan J. $\mathrm{CO}_{2}$ gasification of eucalyptus wood chars. Fuel 1996;75:1505-8.

[85] Ahmed II, Gupta AK. Pyrolysis and gasification of food waste: syngas characteristics and char gasification kinetics. Appl Energy 2010;87:101-8.

[86] Marquez-Montesinos F, Cordero T, Rodriguez-Mirasol J, Rodriguez JJ. $\mathrm{CO}_{2}$ and steam gasification of grapefruit skin char. Fuel 2002;81:423-9.

[87] Mermoud F, Salvador S, Van de Steene L, Golfier F. Influence of the pyrolysis heating rate on the steam gasification rate of large wood char particles. Fuel 2006; $85: 1473-82$.

[88] Mermoud F, Golfier F, Salvador S, Van de Steene L, Dirion JL. Experimental and numerical study of steam gasification of a single charcoal particle. Combust Flame 2006;145:59-79.

[89] Aarna I, Suuberg EM. Changes in reactive surface area and porosity during char oxidation. In: 27th International symposium on combustion, Philadelphia 1998. p. 2933-9.

[90] Commandré JM, Stanmore BR, Salvador S. The high temperature reaction of carbon with nitric oxide. Combust Flame 2002;128:211-6.

[91] Jiang MQ, Zhou R, Hu J, Wang F-C, Wang J. Calcium-promoted catalytic activity of potassium carbonate for steam gasification of coal char: influences of calcium species. Fuel 2012;99:64-71. 
[92] Joyce J, Dixon T, Dinez da Costa J-C. Characterisation of sugar cane waste biomass derived chars from pressurised gasification. Process Saf Environ Prot 2006;84:429-39.

[93] Maschio G, Lucchesi A, Stoppato G. Production of syngas from biomass. Bioresour Technol 1994;48:119-26.

[94] Zhu W, Song W, Lin W. Catalytic gasification of char from co-pyrolysis of coal and biomass. Fuel Process Technol 2008;89:890-6.

[95] Devi TG, Kannan MP. X-ray diffraction (XRD) studies on the chemical states of some metal species in cellulosic chars and the Ellingham diagrams. Energy Fuels 2007;21:596-601.

[96] Gallagher JT, Harker H. Reaction of carbon with oxidizing gases: catalysis by compounds of iron, cobalt, and nickel. Carbon 1964:2:163-73.

[97] Figueiredo JL, Rivera-Utrilla J, Ferro-Garcia MA. Gasification of active carbons of different texture impregnated with nickel, cobalt and iron. Carbon 1987;25:703-8.

[98] Marsh H, Adair RR. Catalytic gasification of doped carbon - a kinetic study. Carbon 1975;13:327-32.

[99] Matas Güell B, van Rossum W, van Swaaij PM, Kersten SRA, Lefferts L, Seshan K. Challenges in the production of sustainable fuels from pyrolysis oil design of efficient catalysts for gasification of char. Appl Catal B Environ 2011;101:587-97.

[100] Wender I, Sternberg H, Friedel R, Metlin S, Markby R. The chemistry and catalytic properties of cobalt and iron carbonyls; bulletin 600 . Washington: US Govt. Print. Off; 1962.

[101] Herrick D, Tiernay J, Huffman G, Wender I. Activity and characterization of coprocessing catalysts produced from iron pentacarbonyl precursor. Energy Fuels 1990;4:231-6.

[102] Bolm C, Legros J, Le Paih J, Zani L. Iron-catalyzed reactions in organic synthesis. Chem Rev 2004;104:6217-54.

[103] Dyson Paul J. Catalysis by low oxidation state transition metal (carbonyl) clusters. Coord Chem Rev 2004;248:2443-58.

[104] Dyson P, McIndoe JS. Transition metal carbonyl cluster chemistry. U.K.: Gordon and Breach Science; 2000. p. 139-42.
[105] King R, King D. Metal carbonyl catalysis of carbon monoxide and formate reactions, vol. 43(9). Russian Chemical Bulletin; 1994. p. 1445-50.

[106] Liu W, Jiang H, Zhang X, ding H, Yu H. Selectively improving the bio-oil quality by catalytic fast pyrolysis of heavy metal polluted biomass: take copper as an example. Environ Sci Technol 2012;46:7849-56.

[107] Neeft JPA, Nijhuis TX, Smakman E, Makkee M, Moulijn JA. Kinetics of the oxidation of diesel soot. Fuel 1997;76:1129-36.

[108] Lahaye J, Boehm, Chambrion Ph, Ehrburger P. Influence of cerium oxide on the formation and oxidation of soot. Combust Flame 1996;104:199-207.

[109] Saracco G, Russo N, Ambrogio M, Badini C, Specchia V. Diesel particulate abatement via catalytic traps. Catal Today 2000;60:33-41.

[110] Stanmore BR, Brilhac J-F, Gilot P. The oxidation of soot - experiments, mechanisms and models. Carbon 2001;39:2247-68.

[111] McKee DW. The copper-catalyzed oxidation of graphite. Carbon 1970;8: 1321-9.

[112] Thomas JM, Walker Jr PL. Mobility of metal particles on a graphite substrate. J Chem Phys 1964;41:587-8.

[113] Devi TG, Kannan MP, Richards GN. Copper catalysis in the air gasification of cellulosic chars. Fuel 1990;69:1440-7.

[114] Devi TG, Kannan MP. Calcium catalysed air gasification of cellullosic chars and jump in reactivity. J Energy Inst 2007;80:88-92.

[115] Devi TG, Kannan MP. Nickel catalysed air gasification of cellullosic chars jump in reactivity. Energy Fuels 2001;15:583-90.

[116] Baker RTK. The relationship between particle motion on a graphite surface and Tammann temperature. J Catal 1982;78:473-6.

[117] Silva IF, Palma C, Klimkiewicz M, Eser S. Kinetics, in situ X-ray diffraction and environmental scanning electron microscopy of activated charcoal gasification catalyzed by vanadium oxide, molybdenum oxide and their eutectic alloy. Carbon 1998;36:861-8.

[118] Yang RT, Wong C. Catalysis of carbon oxidation by transition metal carbides and oxides. J Catal 1984;85:154-68.

[119] Radovic LR, Walker Jr PL, Jenkins RG. Effect of lignite pyrolysis conditions on calcium oxide dispersion and subsequent char reactivity. Fuel 1983;62:209-12. 